\title{
Geochemistry of Major Oxides in Host Rocks in Vizianagarm Manganese Ores Belt (A.P.), India
}

\author{
Farhat Nasim Siddiquie, Mohd Shaif* \\ Department of Geology, Aligarh Muslim University, Aligarh \\ Email: ${ }^{*}$ fnaseem2000@yahoo.com
}

Received 3 March 2015; accepted 6 April 2015; published 10 April 2015

Copyright (C) 2015 by authors and Scientific Research Publishing Inc.

This work is licensed under the Creative Commons Attribution International License (CC BY). http://creativecommons.org/licenses/by/4.0/

(c) $\underset{\mathrm{EY}}{\mathrm{EP}}$ Open Access

\section{Abstract}

The abundance, distribution trends and significance of the major oxides in the host rocks in Vizianagarm Manganese Ores Belt (A.P.) (between $\mathrm{N}$ latitude $18^{\circ} 12^{\prime}$ and $18^{\circ} 30^{\prime}$ and $\mathrm{E}$ longitudes $83^{\circ} 20^{\prime}$ and $\left.83^{\circ} 45^{\prime}\right), 15$ samples of host rocks from different localities of the area under study were collected and analyzed for major oxides. We describe here in major oxides geochemistry of host rocks and manganese ore deposits associated with Precambrian Khondalite and Charnockite in Vizianagarm Manganese Ores Belt (A.P.): 1) Preponderance of $\mathrm{SiO}_{2}$ over $\mathrm{Al}_{2} \mathrm{O}_{3} ; 2$ ) Dominance of $\mathrm{K}_{2} \mathrm{O}$ and $\mathrm{CaO}$ over $\mathrm{Na}_{2} \mathrm{O}$;3) Abnormally high concentration of phosphorus and a positive relationship of $\mathrm{P}_{2} \mathrm{O}_{5}$ with $\mathrm{CaO}$ and Ti contents; 4) Manganese increases with increases of iron, lime and soda and vice versa, 5) CaO increases with the increases of $\mathrm{Al}_{2} \mathrm{O}_{3}, \mathrm{Ti}, \mathrm{K}_{2} \mathrm{O}$ and vice versa. High $\mathrm{P}_{2} \mathrm{O}_{5}$ content in these manganese ores appears to be the result of precipitation from secondary manganese rich solutions containing dissolved phosphorus from the $\mathrm{P}_{2} \mathrm{O}_{5}$ enriched host rocks. Another source of $\mathrm{P}_{2} \mathrm{O}_{5}$ may be the associated granitic and pegmatitic intrusions. Elements like $\mathrm{K}, \mathrm{Na}$, $\mathrm{Ca}$, $\mathrm{Mg}, \mathrm{Co}, \mathrm{Ni}, \mathrm{Pb}$ and $\mathrm{Zn}$ etc. appear to be mostly concentrated in the Mn-minerals viz. psilomelane, cryptomelane, hollandite and pyrolusite and related secondary phases [1] and [2]. Stratigraphically, the study area includes within a thick succession of Precambrian Group belonging to the Khondalite and Charnockite Groups of Dharwar Supergroup, that form a part of Eastern Ghat Complex of India. The manganiferous rocks that have been encountered in the Vizianagarm Manganese Ores Belt (A.P.) India are known as Kodurites.

\section{Keywords}

Vizianagarm, Manganese Ores, Major Oxides, Khondalite, Charnockite, A.P., Geochemistry, Eastern Ghat, Dharwar Supergroup

\footnotetext{
${ }^{*}$ Corresponding author.
}

How to cite this paper: Siddiquie, F.N. and Shaif, M. (2015) Geochemistry of Major Oxides in Host Rocks in Vizianagarm Manganese Ores Belt (A.P.), India. International Journal of Geosciences, 6, 350-372. 


\section{Introduction}

A large number of manganese deposits occur in the Precambrian Eastern Ghats complex of Andhra Pradesh, India. These are dominantly low to medium grade metamorphic deposits with high iron, phosphorus and silica. These manganese bands (deposits) are generally syngenetic and syntectonic with metasedimentry country rock of Khondalite, quartzite and calc-granulites [3].

Manganese ores are widely distributed throughout the Peninsular India. Stratigraphically, these are mainly confined to the Precambrian terrain and are encountered in the Sausar Group and Aravalli Supergroup of central and western India, Iron ore Group and Gangpur Group of eastern India. In Andhra Pradesh, there are major occurrences of manganese ores in Srikakulam-Visakhapatnam Manganese ores belt. The deposit is in this belt over an area of $50 \mathrm{kms}$ in length and $20 \mathrm{~km}$ in width. The study area lies $150 \mathrm{~km}$ NE of Visakhapatnam and includes Garividi, Garbham and Chipurupalle areas (Figure 1). Systematic geochemical study of these manganese ores in the present study area was not carried out by earlier workers. Fifteen samples of host rocks were selected from different localities of the study area. They were analysed for number of major oxides and trace elements.

\section{General Geology and Stratigraphy}

The manganiferous rocks that have been encountered in the Srikakulam-Visakhapatnam manganese belt of Andhra Pradesh belongs to Kodurite Series which is typically exposed at Koduru (18 $16^{\prime}$ : $\left.83^{\circ} 36^{\prime}\right)$ a locality about $80 \mathrm{~km}$ north of Visakhapatnam, the rock series which constitutes an integral part of the Eastern Ghat complex of India. The rock series is composed of an intimate assembalges of metamorphosed argillaceous (garnet-sillimanite gneisses) as at Chipurupalle, Rayagada and Garbham, Arenaceous (Quartzite and garnetiferous

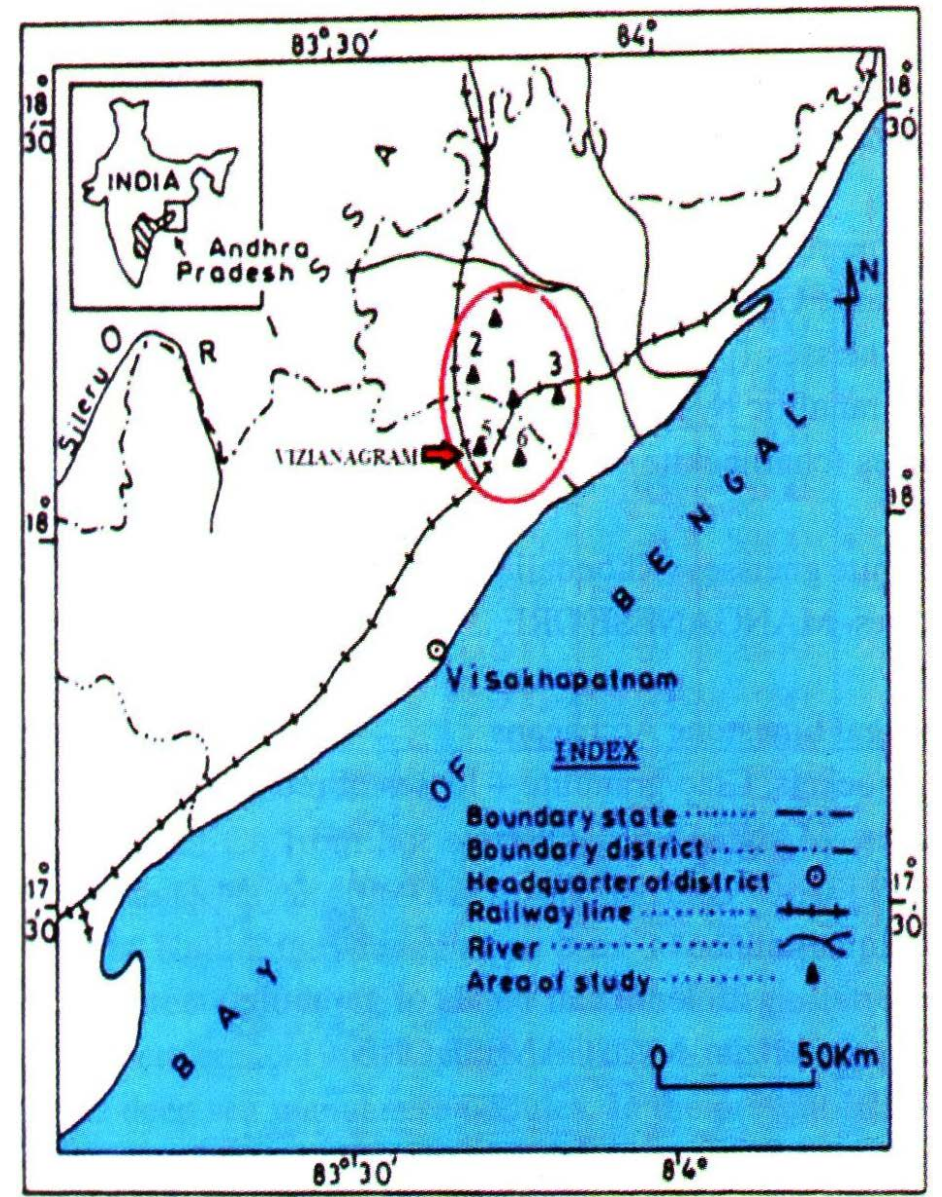

Figure 1. Location map of (1) Garividi, (2) Garbham (3) Chipurupalle manganese deposits, Vizianagram Manganese Ores Belt, (A.P.), India. 
quratzite) as at Garbham, Koduru, Perapi and Avagudem and calcareous sediments (calc-granulites and gneisses) as at Koduru and Gadabavalasa areas, this sequences belonging to granulite facies.

The manganese ores in the area occur primarily in association with calc-granulites, less often with quartzite and still less with the quartz garnet \pm sillimanite graphite gneiss. According to [4] who made radiometric determination of the Precambrain rocks of India, the Eastern Ghat Complex was included in the Precambrain-II (2500 - 3000 m.y.) of the classification of Indian Precambrain rocks. The calc-granulite, quartzite and Khondalites being syn-sedimentary rock bodies, are conformable and co-folded with the associated lithic units such as garnetiferous quartzite, gneisses and garnet-sillimanite gneisses, etc. [5]. Subsequently, granitic and migmatitic activities of different intensities played their respective roles on these metasediments transmuting their earlier textural and mineralogical characters. However, their impact on quartzite and manganese ore is minimal, probably because these units are considered to be the resisters during migmatisation [6]. At places hypersthene gneisses (Charnockite) occur as intrusive bodies in the synsedimentary rock units. All these rocks have in turn been intruded by granite, pegmatite and quartz veins [7].

[8] recongized several rock types ranging from ultrabasic to acidic in the mineralogical composition of Kodurite and ascribed them to differentiation prior to intrusion. [9] indicated that the Kodurite series might be due to hybridism on a large scale in which a granitic intrusion bodily assimilated the manganese of the Khondalites. [10] observed that by and large the manganese ore occurs associated either with quartzite (East Garbham) or with calc-granulite (Sadanandapuram).

However, the geological association in Saibaba main, Saibaba Central, Jai Bhavani-Kottakarra quaries is not clear owing to the highly weathered nature of the rocks. [11] suggested the following stratigraphic succession of the area under study and consider the granites to be intrusive bodies into the Khondalite and Kodurite series.

3 Charnockites

2 Kodurites $\cdots$ Hybrid

Peninsular and Crystalline Complex

1 Calc-granulites, crystalline limestone and associated manganese ores

Garnet-Sillimanite gneisses

Khondalite Series

Quartzite-Garnetiferous, Feldspathic and graphite-bearing

These rocks at places exhibit relict banding. The Garbham main quarry and the Srinavasa quarry at Garbham show weathered calc-granulite-quatzo-feldslpathic rock underlying quartzite. The rock formation and associated manganese ore deposits belonging to the Khondalite and Charnockite suit of metasediments are of the Archaean age [7]. The generalised stratigraphic sequence of the rock formations of Srikakulam area which has been suggested by [7] and supported by [12] is presented as follows:

Granite, pegmatitie and quartz vein

Hypersthese-gneisses (Charnockites?)

Khondalite Series $\left\{\begin{array}{l}\text { Garnet-sillimanite gneisses (khondalites) } \\ \text { Garnet-granulites - Ore horizon I } \\ \text { Calc-granulites } \\ \text { Garnet-granulites - Ore horizon II } \\ \text { Garnet-sillimanite gneissess (khondalites) } \\ \text { Coarse grained quartzites) } \\ \text { Feldspathic quartzite } \\ \text { Garnetiferous quartzite - Ore horizon III } \\ \text { Feldspathic quartzites } \\ \text { Coarse grained quartzites } \\ \text { Garnet-sillimanite gneisses (Khondalites) } \\ \text { Biotite-gneisses }\end{array}\right.$


Crystalline algal limestone belonging to Knondalite Group (Archaean) [13]-[17] and gritty sandstone (Miocene?) in the form of rubble and laterite capping are also observed.

The present authors finds no evidence to differ from the suggestion made by [7] and [18], regarding the stratigraphic succession in Srikakulam except that the occurrence of crystalline algal limestone and shales (red and green) which did not find place in their classification. The modified sequence is presented [13]-[17] as follows:

Some of the earlier workers have also made an attempts to classify and establish the sequence of rock formations encountered at Garividi, Garbham and Chipurupalle areas (Table 1 and Figure 2). They are as follows:

Garividi area [10]

Soil

Laterite-pisolites and concretions of

Mn-ore and calc-tufa

Pegmatite and quartz veins

Granites/garnetiferous biottie gneiss

Garnet-sillimanite gneiss (with or without graphite)

Calc-granulite and lenticles of crystalline limestone

Manganese ore and garnet granulites

Quartz-feldspar rock with occasional incidence of apatite

Garnet-sillimanite gneiss interlayered with quartzite and occasional lenticles of crystalline limestone

Garham Area [10]

Soil

Laterite-calc tufa calcreta

Pegmatite $\left\{\begin{array}{l}\text { pegmatite and quartz veins } \\ \text { Garnet/granite gneiss } \\ \text { Garnetiferous and non-garnetiferous quartzo-feldspathic rock } \\ \text { Biotite-gneiss }\end{array}\right.$

Charnockite

Garnet-sillimanite gneiss with or without graphite

Calc-granulite with manganese ore associated with bands and pockets of lithomarge and highly kaolinised

Table 1. Geological succession of the Garividi area, Srikakulam-Visakhapatnam belt (A.P.).

\begin{tabular}{cl}
\hline Age & Group \\
$\begin{array}{c}\text { Recent } \\
\text { Meistocene (?) }\end{array}$ & Rock types \\
Alluvium and soil \\
Laterite-limonite and ochre \\
Sandstone \\
Pegmatite and quartz vein \\
Granite and granite gneisses \\
Hypersthene gneisses (porphyro-blastic) (Charnockite) \\
granulitic hypersthene diorite and granite gneisses \\
(Charnockite) \\
Garnet sillimanite gneisses \\
(Khondalite) \\
Garnet granulite-MAGANESE ORE HORIZON - I \\
Group
\end{tabular}

Two horizons were not reported by earlier workers, reported for the first time [15] and [19]. 


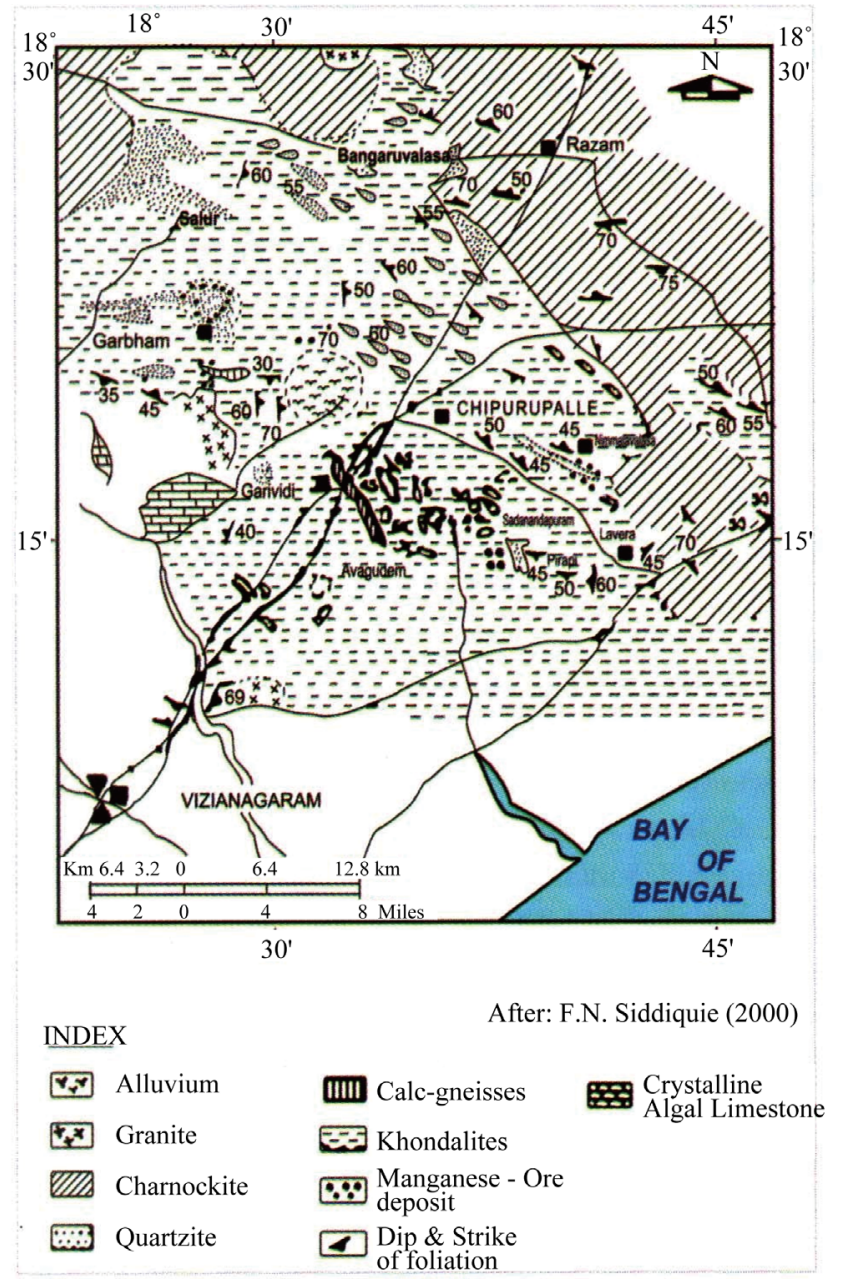

Figure 2. A generalised geological map of Garividi, Garbham and Chipurupalle manganese deposits, Vizianagram district (A.P.), India.

quartzo-feldspathic apatite rock, the latter in the majority of cases seen underlying the Mn-ore zone.

Calc-granulite highly weathered with intermixture of quartz-feldspar-apatite rock

Manganese ore with chert and lemonite quartzite

Garnet-sillimanite gneiss (with or without graphite) interlayered with quartzite

Chirpurupalle area [20]

Archaean $\left\{\begin{array}{l}\text { Recent laterite and loamy alluvium } \\ \text { Granite gneisses } \\ \text { Manganese rich rocks, "Kodurites" } \\ \text { Khondalite series: } \\ \text { Calc-granulites } \\ \text { Quartz-garnet-sillimanite gneisses } \\ \text { Quartzites }\end{array}\right.$

\section{Major Oxides in Host Rocks}

\section{General Statement}

In the area of study, the host rocks for manganese mineralization, are mainly Khondalite and Charnockite Group 
of rocks.

Fifteen samples of host rocks were selected out of a large number of samples collected for their chemical analysis out of which ten samples were of Khondalites and remaining five of Charnockites. The samples were analysed chemically for the determination of their major oxides- $\mathrm{SiO}_{2}, \mathrm{Al}_{2} \mathrm{O}_{3}, \mathrm{TiO}_{2}, \mathrm{MnO}, \mathrm{Fe}_{2} \mathrm{O}_{3}, \mathrm{FeO}, \mathrm{P}_{2} \mathrm{O}_{5}$, MgO, $\mathrm{CaO}, \mathrm{Na}_{2} \mathrm{O}, \mathrm{K}_{2} \mathrm{O}$ and $\mathrm{H}_{2} \mathrm{O}^{+}$and some trace elements which are discussed [21]. The relative variation trends of various major oxides are shown in Figure 3. The analytical data are presented in Table 2.

\section{Distribution of the Major Oxides}

The abundance and variation range with average (wt\%) of different major oxides of Khondalites and Charnockites are given in (Table 2 and Table 3) and the distribution of various major oxides are discussed as below:

\subsection{Silica $\left(\mathrm{SiO}_{2}\right)$}

The quantitative variation trend of silica in the host rocks from 47.84 percent to 70.45 percent and gives an average value of 61.81 percent (Table 3, Figure 3). Khondalite, Charnockite rocks have wide variation of silica (Table 3). [22] reported $58.04 \%$ to $74.38 \% \mathrm{SiO}_{2}$ from Srikakulam area, [11] reported 58.4\% from Garividi, [23] reported $67.10 \%$ and $69.90 \%$ respectively from Charnockites of Tamil Nadu and Karnataka. The histogram (Figure 4(a)) represents frequency percent distribution, showing polymodal nature of $\mathrm{SiO}_{2}$ in the host rocks. The maxima is at 65 - 70 percent class. The typical mode of $\mathrm{SiO}_{2}$ falls between 65 - 70 percent.



Figure 3. Variation diagrams of major oxides in Khondalite and Charnockite Groups of Garividi, Garbham and Chipurupalle areas, Srikakulam-Visakhapatnam Belt (A.P.). 
Table 2. Distribution of major oxides of Khondalite and Charnockite Groups of Garividi, Garbham and Chipurupalle areas, Srikakulam-Visakhapatnam Belt (A.P.).

\begin{tabular}{|c|c|c|c|c|c|c|c|c|c|c|c|c|c|c|c|}
\hline & KD1 & KD2 & KD3 & KD4 & KD5 & KD6 & KD7 & KD8 & KD9 & KD10 & CK11 & CK12 & CK13 & CK14 & CK15 \\
\hline $\mathrm{SiO}_{2}$ & 69.35 & 70.3 & 7 & 48.84 & 56.1 & 68.46 & 58.29 & 52.24 & 56.1 & 59 & 64.16 & 69.09 & 70.45 & 68 & 47.84 \\
\hline $\mathbf{A l}_{2} \mathbf{O}_{3}$ & 13.09 & 13.45 & 16.75 & 12 & 13.4 & 10.94 & 32 & 17.42 & 16.34 & 16.02 & 5.66 & 13.35 & 13.12 & 16.4 & 7.42 \\
\hline MnO & 0.12 & 0.12 & 0.21 & 0.94 & 0.36 & 0.08 & 0.21 & 0.4 & 0.5 & 0.52 & 0.38 & 0.12 & 0.3 & 0.26 & 0.9 \\
\hline $\mathrm{Fe}_{2} \mathrm{O}_{3}$ & 1.21 & 1.16 & 3.36 & 1.3 & 106 & 044 & 0.54 & 2.2 & 4 & 222 & 2.07 & 1.21 & 1.64 & 3.36 & 2.3 \\
\hline $\mathrm{FeO}$ & 4.52 & 3.64 & 4.6 & 13.11 & 7.19 & 1 & 1.45 & 7.48 & 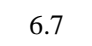 & 5.74 & 4.25 & 3.16 & 4.59 & 12.11 & 7.2 \\
\hline $\mathbf{P}_{2} \mathbf{O}_{5}$ & 0.24 & 0 & 0.3 & n.d. & 0 & 0.42 & 0.36 & 0.45 & 0.35 & 0.33 & 0.32 & 0.51 & 0.1 & 0.35 & 0.14 \\
\hline $\mathrm{TiO}_{2}$ & 0.73 & 0.4 & 0.47 & 0.6 & 0.79 & 0.58 & 1.18 & 9 & 1.45 & 0.72 & 0.44 & 0.72 & 0.6 & 0.48 & 0.6 \\
\hline $\mathrm{CaO}$ & 2.37 & 2.42 & 1.25 & 19.83 & 16.2 & 12.44 & 25.61 & 8.86 & 7.3 & 6.7 & . & 2.33 & 2. & 1.25 & 19.83 \\
\hline MgO & 0.86 & 1.09 & 0.86 & 7.9 & 4.14 & 4.17 & 4.58 & 5.8 & 5.03 & 4.6 & 3.12 & 1.9 & 1.11 & 0.86 & 6.9 \\
\hline $\mathrm{Na}_{2} \mathrm{O}$ & 1.52 & 16 & 0.34 & 0.67 & 0.7 & 1.2 & 1.6 & 2.48 & 2.56 & 2.08 & 2.84 & 0.56 & 1.4 & 2.16 & 1.67 \\
\hline $\mathbf{K}_{2} \mathbf{O}$ & 5.94 & 4.96 & 2.16 & 0.02 & 0.24 & 0.16 & 0.2 & 0.64 & 1.42 & 0.9 & 2. & 5.9 & 4.97 & 2.09 & 0.02 \\
\hline $\mathbf{H}_{2} \mathbf{O}^{+}$ & 0.51 & 0.53 & 0.49 & 0.62 & 0.35 & 0.8 & 0.5 & 0.96 & 0.3 & 0.5 & 0.3 & 0.52 & 0.52 & 0.34 & 0.62 \\
\hline Total & 100.46 & 99.77 & 100.79 & 100.25 & 100.63 & 100.89 & 100.76 & 99.55 & 100.33 & 100.4 & 100.43 & 100.46 & 99.77 & 100.14 & 100.35 \\
\hline
\end{tabular}

KD = Khondalite; $\mathrm{CK}=$ Charnokite; n.d. = Not Detectable .

Table 3. Range of variation and average oxide \% of Khondalite and Charnockite Groups of Garividi, Garbham and Chipurupalle areas, Srikakulam-Visakhapatnam Belt (A.P.).

\begin{tabular}{cccc}
\hline Oxides & Minimum & Maximum & Average \\
$\mathbf{S i O}_{2}$ & 47.84 & 70.45 & 61.81 \\
$\mathbf{A l}_{2} \mathbf{O}_{3}$ & 6.32 & 17.42 & 13.07 \\
$\mathbf{T i O}_{2}$ & 0.12 & 0.94 & 0.36 \\
$\mathbf{M n O}$ & 0.44 & 3.36 & 1.45 \\
$\mathbf{F e}_{2} \mathbf{O}_{3}$ & 1.20 & 13.11 & 5.79 \\
$\mathbf{F e O}$ & 0.10 & 0.51 & 0.27 \\
$\mathbf{P}_{2} \mathbf{O}_{5}$ & 0.40 & 1.45 & 0.70 \\
$\mathbf{C a O}$ & 1.25 & 25.61 & 8.80 \\
$\mathbf{M g O}$ & 0.86 & 7.90 & 3.52 \\
$\mathbf{N a}_{2} \mathbf{O}$ & 0.34 & 2.84 & 1.55 \\
$\mathbf{K}_{2} \mathbf{O}$ & 0.02 & 5.94 & 2.12 \\
$\mathbf{H}_{2} \mathbf{O}^{+}$ & 0.30 & 0.96 & 0.52 \\
\hline
\end{tabular}

\subsection{Alumina $\left(\mathrm{Al}_{2} \mathrm{O}_{3}\right)$}

The quantitative variation trend of Alumina in the host rocks of the study area ranges 6.32 percent to 17.42 percent and gives an average value of 13.07 percent (Table 3).

Khondalite and charnockite rocks show wide variation of $\mathrm{Al}_{2} \mathrm{O}_{3}$ (Table 3). [22] reported 9.65\% to 20.64\% $\mathrm{Al}_{2} \mathrm{O}_{3}$ from Srikakulam area. [24] reported $14.08 \%$ from feldspar garnetiferous granite-gneiss of Peddapantupalli, and [23] reported $14.10 \%$ and $15.10 \%$ from Charnockites of Tamil Nadu and Karnataka. The histogram (Figure 4(b)) represents frequency percent distribution, showing polymodal nature of $\mathrm{Al}_{2} \mathrm{O}_{3}$. The maxima is at 12 - 14 and 16 - 18 percent classes. 


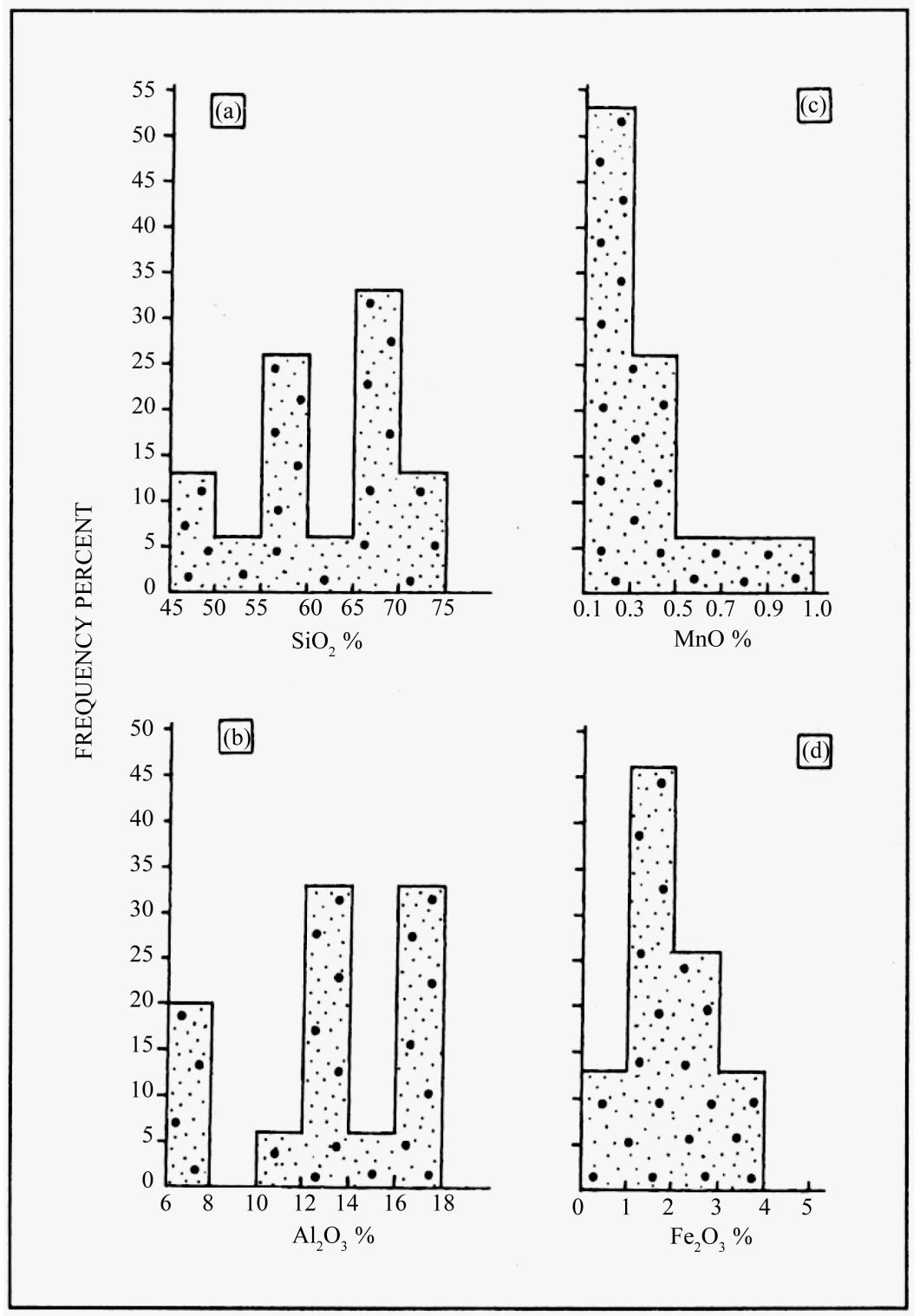

Figure 4. Histograms showing frequency percent distribution of $\mathrm{SiO}_{2}, \mathrm{MnO}, \mathrm{Al}_{2} \mathrm{O}_{3}$ and $\mathrm{Fe}_{2} \mathrm{O}_{3}$ in Khondalite and Charnockite Groups of Garividi, Garbham and Chipurupalle areas, Srikakulam-Visakhapatnam Belt (A.P.).

\subsection{Manganese ( $\mathrm{MnO})$}

The quantitative variation trend of manganese monoxide in the Khondalite and Charnockite rocks ranges from 0.12 percent to 0.94 percent and gives an average value of 0.36 percent (Table 3 ).

[22] reported $0.09 \%$ to $3.70 \%$ from the Srikakulam area whereas Khondalites of Sri Lanka consist $0.18 \%$ $\mathrm{MnO}$ [25], [23] reported 0.05\% and 0.02\% from Charnockites of Tamil Nadu and Karnatka.

The histogram (Figure 4(c)) represents frequency percent distribution, showing unimodal positively skewed nature of $\mathrm{MnO}$. The maxima is at 0.1 to 0.3 percent class and the typical mode of $\mathrm{MnO}$ also lies in the same class.

\subsection{Ferric Oxide $\left(\mathrm{Fe}_{2} \mathrm{O}_{3}\right)$}

The quantitative variation trend of $\mathrm{Fe}_{2} \mathrm{O}_{3}$ in the host rocks ranges from 0.44 percent to 3.36 percent and gives an 
average value of 1.45 percent (Table 3 ).

[22] reported $0.86 \%$ to $3.76 \%$ from Srikakulam area. [24] reported $1.22 \%$ from feldspar garnetiferous granite-gneiss of Peddapantupalli area, [23] reported 4.36\% and 2.36\% from the Charnockite of Tamil Nadu and Karnataka (Table 3 and Table 4).

The histogram (Figure 4(d)) represents frequency percent distribution, showing unimodal positively skewed nature of $\mathrm{Fe}_{2} \mathrm{O}_{3}$. The maxima is at 1 to 2 percent class and the typical mode also lies in the same class.

\subsection{Ferrous Oxide (FeO)}

The quantitative variation trend of $\mathrm{FeO}$ in the host rocks ranges from 1.20 percent to 13.11 percent and gives and average value of 5.79 percent (Table 3 and Table 4).

The Khondalites and Charnockites having higher concentration of $\mathrm{FeO}$ as compared to $\mathrm{Fe}_{2} \mathrm{O}_{3}$ (Table 3 and Table 4), [22] reported $1.12 \%$ to $8.04 \%$ from same area, [26] reported $9.98 \%$ from hypersthene-granulite of Narasimhunipeta, [11] reported 8.04\% from Khondalites of Garividi and [23] reported 3.60\% and 1.30\% from Charnockites of Tamil Nadu and Karnataka (Table 3 and Table 4).

The histogram (Figure 5(a)) represents frequency percent distribution, showing polymodal nature of FeO. The maxima is at 3 to 5 percent class and typical mode also lies in the same class.

\subsection{Phosphorus $\left(\mathrm{P}_{2} \mathrm{O}_{5}\right)$}

The quantitative variation trend of $\mathrm{P}_{2} \mathrm{O}_{5}$ in the host rocks ranges from $0.10 \%$ to $0.51 \%$ and gives an average value of 0.27 percent (Table 3 , and Table 4).

The concentration of $\mathrm{P}_{2} \mathrm{O}_{5}$ is abnormally on the higher side in the manganese ores as well as in the host rock of the study area, whereas [22] reported $0.18 \%$ to $1.01 \%$ from the various areas of Srikakulam district, [11] reported $0.75 \%$ from Khondalites of Garividi, and [24] reported $0.24 \%$ from feldspar garnetiferous granite-gneiss of peddapantupalli (Table 3 and Table 4).

The histogram (Figure 5(b)) represents frequency percent distribution, showing bimodal nature of $\mathrm{P}_{2} \mathrm{O}_{5}$. The maxima is at $0.3 \%$ to $0.4 \%$ class. The typical mode of $\mathrm{P}_{2} \mathrm{O}_{5}$ is also lies between 0.3 percent to 0.4 percent class.

\subsection{Titania $\left(\mathrm{TiO}_{2}\right)$}

The quantitative variation trend of $\mathrm{TiO}_{2}$ in the host rocks ranges 0.40 percent to 1.45 percent and gives an average value of 0.70 percent (Table 3 ).

Table 4. Average major oxide (wt\%) of the host rocks (Khondalite and charnokite) compared with other Khondalites and Charnockites.

\begin{tabular}{|c|c|c|c|c|c|c|c|c|}
\hline & I & II & III & IV & $\mathbf{V}$ & VI & VII & VIII \\
\hline $\mathrm{SiO}_{2}$ & 60.86 & 63.90 & 68.36 & 60.75 & 60.08 & 58.04 & 67.10 & 69.90 \\
\hline $\mathbf{A l}_{2} \mathbf{O}_{3}$ & 13.01 & 13.19 & 14.08 & 14.49 & 12.38 & 17.30 & 14.10 & 15.10 \\
\hline $\mathrm{TiO}_{2}$ & 0.77 & 0.56 & 0.73 & 0.36 & 0.65 & 1.65 & 0.80 & 0.41 \\
\hline $\mathrm{Fe}_{2} \mathrm{O}_{3}$ & 1.49 & 2.10 & 1.22 & 1.75 & 3.28 & 1.20 & 4.36 & 2.36 \\
\hline FeO & 5.70 & 5.97 & 4.51 & 9.98 & 4.20 & 8.04 & 3.60 & 1.30 \\
\hline MnO & 0.35 & 0.39 & 0.11 & 0.10 & 0.18 & 2.27 & 0.05 & 0.02 \\
\hline MgO & 3.90 & 2.77 & 0.85 & 3.26 & 1.95 & 5.90 & 2.31 & 1.09 \\
\hline $\mathrm{CaO}$ & 10.30 & 5.80 & 2.37 & 5.10 & 9.43 & 1.40 & 2.82 & 3.20 \\
\hline $\mathrm{Na}_{2} \mathrm{O}$ & 1.47 & 1.72 & 1.52 & 2.62 & 2.59 & 0.88 & 3.91 & 4.79 \\
\hline $\mathbf{K}_{2} \mathbf{O}$ & 1.66 & 3.03 & 5.93 & 1.20 & 3.06 & 3.24 & 2.23 & 1.49 \\
\hline $\mathbf{P}_{2} \mathbf{O}_{5}$ & 0.26 & 0.28 & 0.24 & 0.05 & - & 0.75 & 0.02 & 0.08 \\
\hline $\mathbf{H}_{2} \mathbf{O}$ & 0.55 & 0.46 & 0.44 & 0.51 & 1.80 & 0.15 & 0.47 & 0.16 \\
\hline
\end{tabular}




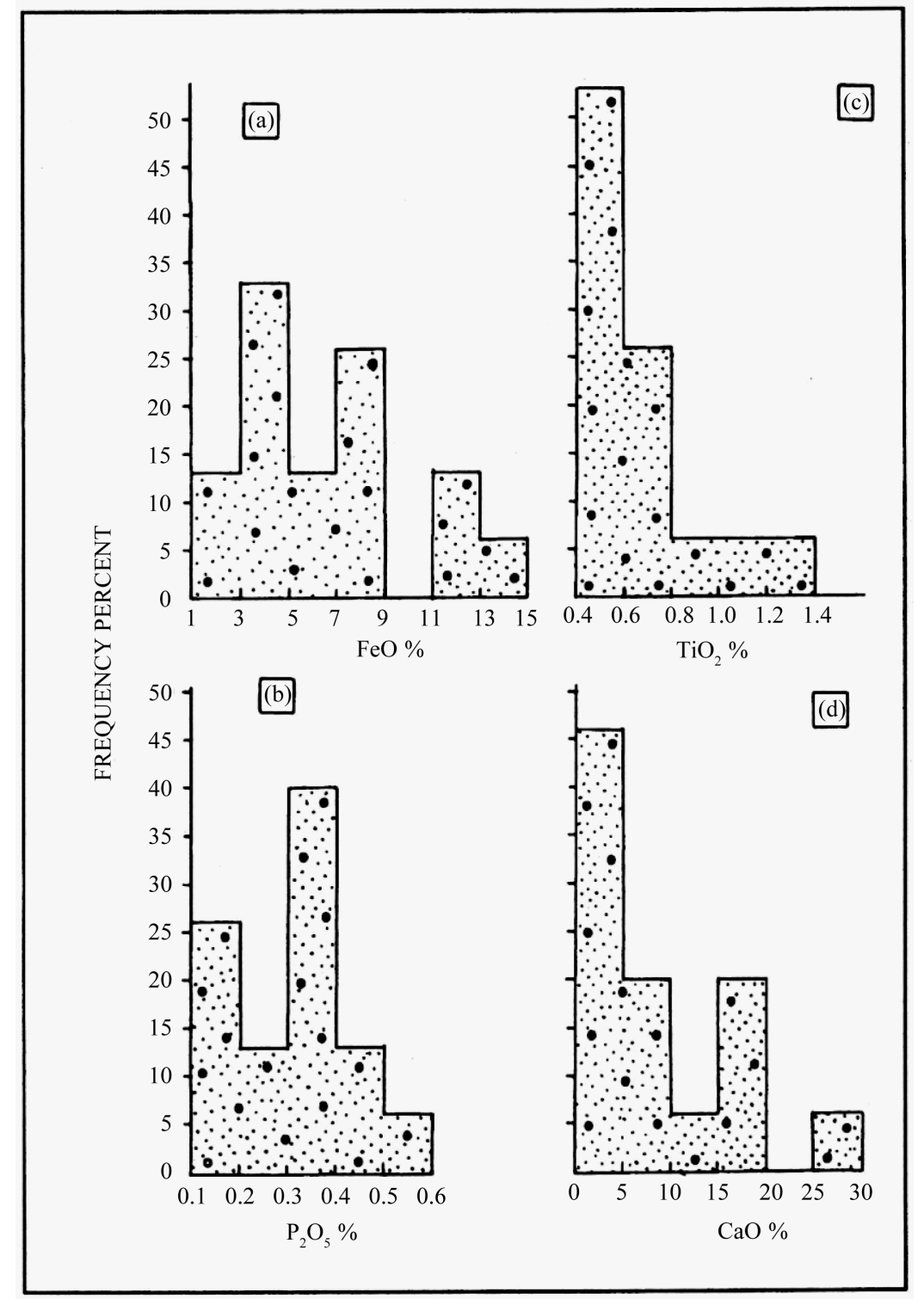

Figure 5. Histograms showing frequency percent Distribution of $\mathrm{FeO}, \mathrm{TiO}_{2}, \mathrm{P}_{2} \mathrm{O}_{5}$ and $\mathrm{CaO}$ in Khondalite and Charnockite Groups of Garividi, Garbham, and Chipurupalle areas, Srikakulam-Visakhapatnam Belt (A.P.).

[24] reported $0.73 \%$ from feldspar garnetiferous granite-gneiss of Peddapantupalli, Khondalite of Sri Lanka shows $0.65 \% \mathrm{TiO}_{2}$ [25]. [11] reported $1.65 \%$ from Khondalite of Garividi and [23] reported $0.80 \%$ and $0.41 \%$ from Charnockites of Tamil Nadu and Karnataka.

The histogram (Figure 5(c)) represents frequency percent distribution showing unimodal, positively skewed nature of $\mathrm{TiO}_{2}$. The maxima is at 0.4 to 0.6 percent class and the typical mode also lies between 0.4 to 0.6 percent class.

\subsection{Lime ( $\mathrm{CaO})$}

The quantitative variation trend of calcium oxide in the host rocks of the study area ranges from 1.25 percent to 25.61 and gives and average value of 8.80 percent (Table 3 and Table 4).

The $\mathrm{CaO}$ in the Khondalites and Charnockites of the study area shows a wide variation range from $1.25 \%$ to 25.61\% (Table 3 and Table 4), Rao, K.V.R. (1955) reported 5.10\% from hypersthene-granulite from the Nara- 
simhunipeta and Krishnan (1934) reported 9.43\% CaO in Khondalites of Sri Lanka (Table 3 and Table 4).

The histogram (Figure 5(d)) represents frequency percent distribution, showing bimodal nature of $\mathrm{CaO}$. The maxima is at 1 percent to 5 percent class. The typical mode lies between 1 percent to 5 percent class.

\subsection{Magnesia (Mg0)}

The quantitative variation trend of $\mathrm{MgO}$ in the host rocks ranges from 0.86 percent to 7.90 percent and gives and average value of 3.52 percent (Table 3 and Table 4).

Rao, K.V.R. (1955) reported 3.26\% from hypersthene-granulite of narasimhunipeta, [11] reported 5.90\% from Khondalites of Garividi and [23] reported 2.31\% from Charnockites of Tamil Nadu (Table 3 and Table 4).

The histogram (Figure 6(a)) represents frequency percent distribution, showing bimodal nature of MgO. The typical mode of $\mathrm{MgO}$ and maxima lie between 0 to 2 and 4 to 6 percent classes.

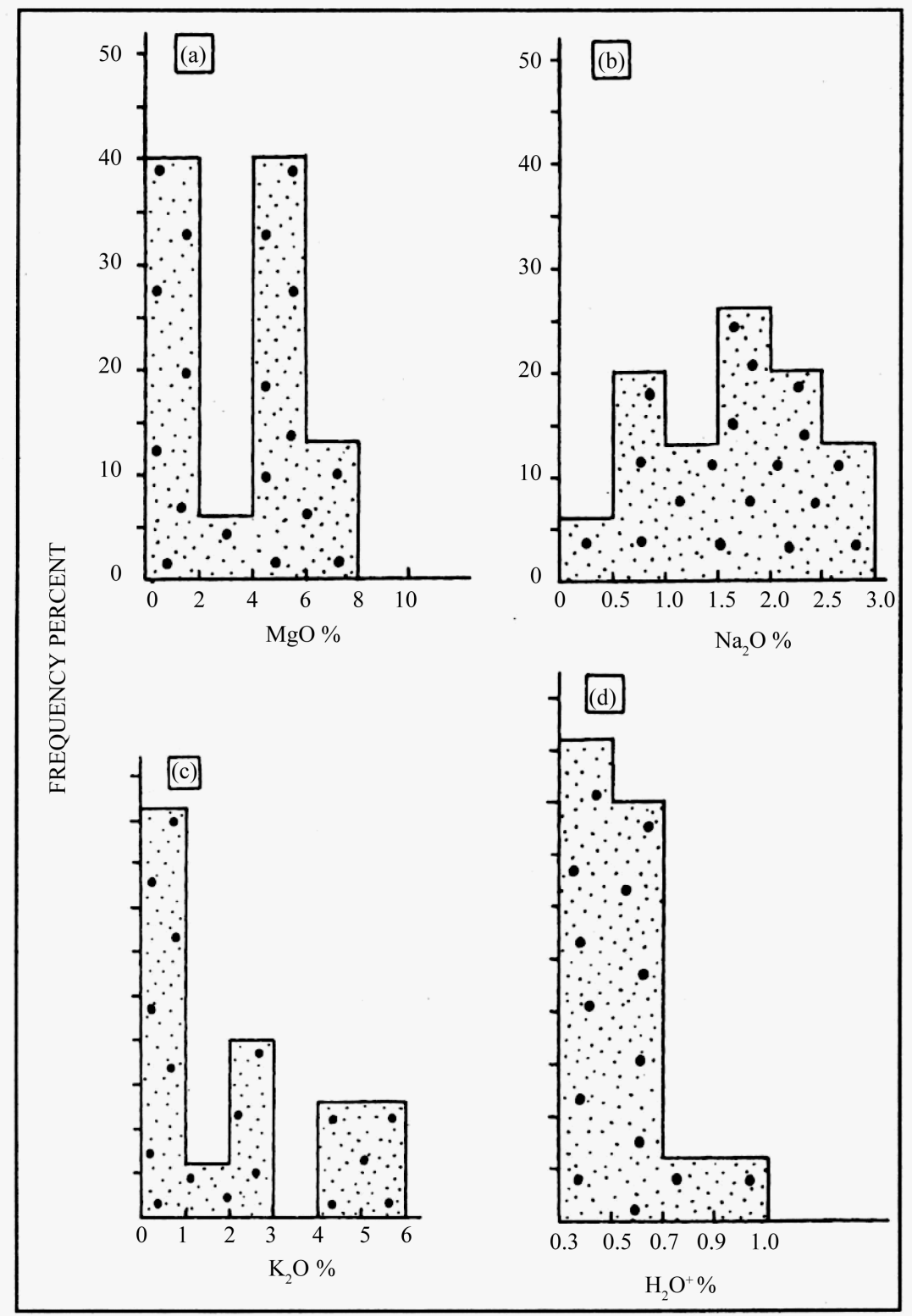

Figure 6. Histograms showing frequency percent distribution of $\mathrm{MgO}, \mathrm{K}_{2} \mathrm{O}, \mathrm{Na}_{2} \mathrm{O}$ and $\mathrm{H}_{2} \mathrm{O}^{+}$in Khondalite and Charnockite Groups of Garividi, Garbham and Chipurupalle areas, Srikakulam-Visakhapatnam Belt (A.P.). 


\subsection{Soda $\left(\mathrm{Na}_{2} \mathrm{O}\right)$}

The quantitative variation trend of $\mathrm{Na}_{2} \mathrm{O}$ in the host rocks ranges from 0.34 percent to 2.84 percent and gives an average value of 1.55 percent (Table 3 and Table 4).

Rao, K.V.R. (1955) reported 2.62\% from hypersthene granulite of Narasimhunipeta, 2.59\% reported in Khondalites of Sri Lanka Krishnan (1934), and [23] reported 3.91\% and 4.79\% from Charnockites of Tamil Nadu and Karnataka (Table 4).

The histogram (Figure 6(b)) represents frequency percent distribution, showing polymodal nature of $\mathrm{Na}_{2} \mathrm{O}$. The maxima is at 1.5 percent to 2.0 percent class, and the typical mode also lies in the same class.

\subsection{Potash $\left(\mathrm{K}_{2} \mathrm{O}\right)$}

The quantitative variation trend of $\mathrm{K}_{2} \mathrm{O}$ in the host rock ranges from 0.02 percent to 5.49 percent and gives an average value of 2.12 percent. [24] reported 5.93\% from feldspar garnetiferous granite-gneiss of peddapantupalli, 3.06\% reported from Khondalites of Sri Lanka [25].

[11] reported 3.24\% from Khondalites of Garividi, and [23] reported 2.23\% from Charnockites of Tamil Nadu (Table 4).

The histogram (Figure 6(c)) represents frequency percent distribution, showing polymodal nature of $\mathrm{K}_{2} \mathrm{O}$. The maxima is at 0 to 1 percent class and typical mode also lies in the same class.

The Khondalites and Charnockites have wide variation of potassium oxide. This higher amount of $\mathrm{K}_{2} \mathrm{O}$ is due to the presence of potash feldspar and micaceous mineral in these rocks. The high potash contents in Khondalites and Charnockites are possibly due to the migmatisation, which took place by the injection of feldspathic (K-feldspar) fluid. The megacrystic K-feldspar in them crystallised from the injected fluid and also by the segregation of the neo-mobilised feldspathic components during migmatisation. According to [27], the main supply of alkalies came probably from the intrusive igneous rocks, another probable source might be the quartz with its numerous fluid inclusion.

\subsection{Water $\left(\mathrm{H}_{2} \mathrm{O}^{+}\right)$}

The quantitative variation trend of $\mathrm{H}_{2} \mathrm{O}^{+}$in the host rocks ranges from $0.30 \%$ to $0.96 \%$ and gives an average value of 0.52 percent.

[24] reported $0.44 \%$ from feldsdpar garnetiferous granite-gneiss of peddapantupalli, [26] reported $0.51 \%$ from hypersthene-granulite of Narasihunipeta, and [23] reported 0.47\% from Charnockites of Tamil Nadu.

The histogram (Figure 6(d)) represents frequency percent distribution, showing unimodal positively skewed nature of $\mathrm{H}_{2} \mathrm{O}^{+}$. The maxima is at 0.3 to 0.5 percent and typical mode also lies in the same class.

\section{Mutual Relationship}

An attempt has been made to determine the geochemical relationship of $\mathrm{MnO}$ with $\mathrm{SiO}, \mathrm{Al}_{2} \mathrm{O}_{3}, \mathrm{FeO}, \mathrm{K}_{2} \mathrm{O}, \mathrm{Na}_{2} \mathrm{O}$, $\mathrm{CaO}$ (Figures 7(a)-(f)), and $\mathrm{Fe}_{2} \mathrm{O}_{3}$ in Khondalite and Charnockite Groups of Garividi, Garbham and Chipurupalle areas, Srikakulam-Visakhapatnam Belt (A.P.). The mutual relationships of significant oxides are plotted in various diagrams and discussed as follows:

\subsection{Silica $\left(\mathrm{SiO}_{2}\right)$}

The computed correlation coefficient of silica shows strongly antipathetic relationship with MnO (Figure 7(a)) and $\mathrm{FeO}$ (relationship of $\mathrm{SiO}_{2}$ with $\mathrm{Fe}_{2} \mathrm{O}_{3}$ and $\mathrm{FeO}$ and $\mathrm{Al}_{2} \mathrm{O}_{3}$ with $\mathrm{Fe}_{2} \mathrm{O}_{3}$ in Khondalite and Charnockite Groups of Garividi, Garbham and Chipurupalle areas, Srikakulam-Visakhapatnam Belt (A.P.)) and MgO and shows slightly negative relationship with $\mathrm{TiO}_{2}, \mathrm{Na}_{2} \mathrm{O}$ and $\mathrm{H}_{2} \mathrm{O}^{+}$(Table 5).

These relationships reveal that with the increase of $\mathrm{SiO}_{2}$ there is correspondingly decrease in $\mathrm{MnO}, \mathrm{FeO}, \mathrm{TiO}_{2}$, $\mathrm{CaO}, \mathrm{MgO}, \mathrm{Na}_{2} \mathrm{O}$ and $\mathrm{H}_{2} \mathrm{O}^{+}$and vice versa. The negative relationship of silica with manganese and $\mathrm{FeO}$ probably indicates that manganese and $\mathrm{FeO}$ are the substitutes of silica. It appears that the negative relationship of $\mathrm{MnO}$ with silica is possibly due to the alteration of manganese bearing minerals into silicate minerals. The highly variable silica/alumina ratio (Table 6) and sympathetic relationship of silica with $\mathrm{Al}_{2} \mathrm{O}_{3}, \mathrm{Fe}_{2} \mathrm{O}_{3}$ and $\mathrm{K}_{2} \mathrm{O}$ favours the coexistence of quartz and aluminosilicate minerals in the Khondalite and Charnockite rocks. The 

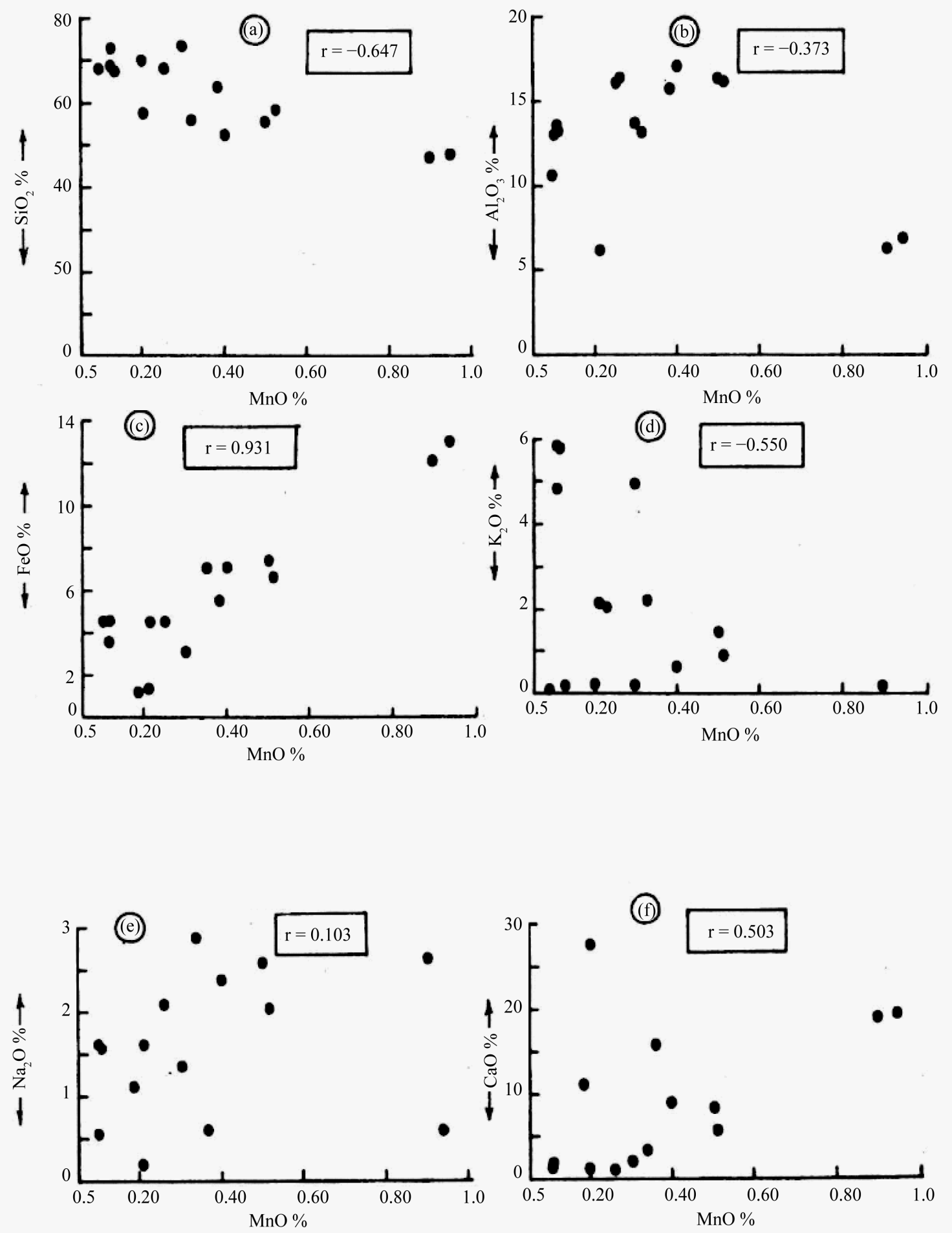

Figure 7. Relationship of $\mathrm{MnO}$ with $\mathrm{SiO}_{2}, \mathrm{Al}_{2} \mathrm{O}_{3}, \mathrm{FeO}, \mathrm{K}_{2} \mathrm{O}, \mathrm{Na}_{2} \mathrm{O}$ and $\mathrm{CaO}$ in Khondalite and Charnockite Groups of Garividi, Garbham and Chipurupalle areas, Srikakulam-Visakhapatnam Belt (A.P.). 
Table 5. Correlation coefficient between the various constituents of Khondalite and Charnockite Groups of Garividi, Garbham and Chipurupalle areas, Srikakulam-Visakhapatnam Belt (A.P.).

\begin{tabular}{|c|c|c|c|c|c|c|c|c|c|c|c|c|c|c|c|c|c|c|c|c|}
\hline S.No. & $\mathrm{SiO}_{2}$ & ${ }_{2} \mathbf{A l}_{2} \mathbf{O}_{3}$ & MnO & $\mathrm{Fe}_{2} \mathbf{O}_{3}$ & $\mathrm{FeO}$ & $\mathbf{P}_{2} \mathbf{O}_{5}$ & $\mathrm{TiO}_{2}$ & $\mathrm{CaO}$ & MgO & $\mathrm{Na}_{2} \mathrm{O}$ & $\mathrm{K}_{2} \mathrm{O}$ & $\mathbf{H}_{2} \mathbf{O}^{+}$ & $\mathrm{Ni}$ & Co & $\mathrm{Pb}$ & $\mathrm{Zn}$ & $\mathrm{Cr}$ & $\mathrm{Sr}$ & V & $\mathrm{Li}$ \\
\hline $\mathrm{SiO}_{2}$ & 1 & 0.3863 & -0.0348 & 0.0348 & -0.7988 & 0.2349 & -0.4119 & -0.7385 & -0.9348 & -0.1741 & 10.7329 & -0.2199 & 0.1747 & 0.0957 & 0.6072 & $2-0.2634$ & 340.0899 & 0.0178 & -0.2974 & 40.0779 \\
\hline MnO & & & 1 & 0.1993 & 0.9319 & -0.474 & 0.0923 & 0.5032 & 0.7941 & 0.1035 & -0.5504 & 40.0573 & -0.0163 & 30.2032 & -0.249 & 90.0689 & $9-0.2299$ & $9-0.219$ & 0.1018 & 0.1688 \\
\hline $\mathrm{Fe}_{2} \mathrm{O}_{3}$ & & & & 1 & 0.2476 & 0.0803 & -0.3351 & $1-0.4456$ & -0.2154 & 0.1929 & -0.0402 & $2-0.1686$ & 50.3964 & 0.6076 & 0.2426 & $6-0.3531$ & 310.1611 & -0.3805 & $5-0.1415$ & 50.091 \\
\hline FeO & & & & & 1 & -0.467 & 0.0407 & 0.3514 & 0.6977 & 0.0139 & -0.4058 & 80.0484 & -0.1092 & 20.1699 & -0.2559 & 990429 & -0.0546 & $6-0.0091$ & 10.1808 & 0.0044 \\
\hline $\mathbf{P}_{2} \mathbf{O}_{5}$ & & & & & & 1 & 0.298 & -0.2433 & -0.1491 & 0.2804 & 0.0272 & 0.1629 & 0.2422 & 0.1302 & -0.1324 & 40.0787 & 70.2954 & -0.3134 & 40.3457 & -0.3347 \\
\hline $\mathrm{TiO}_{2}$ & & & & & & & 1 & 0.3417 & 0.3732 & 0.2686 & -0.2434 & $4-0.0778$ & $3-0.1786$ & 6-0.4448 & $8-0.5717$ & 70.4041 & 0.2491 & 0.0493 & 0.5239 & -0.1731 \\
\hline $\mathrm{CaO}$ & & & & & & & & 1 & 0.7822 & -0.1503 & $3-0.7267$ & $\begin{array}{ll}7 & 0.2387\end{array}$ & -0.225 & -0.3526 & 6-0.5382 & 320.1953 & -0.2272 & 20.0612 & 0.238 & 0.0786 \\
\hline $\mathrm{Na}_{2} \mathrm{O}$ & & & & & & & & & & 1 & -0.1265 & $5-0.1089$ & 0.0251 & 0.3904 & -0.0253 & 30.0677 & 70.1261 & -0.3141 & $1-0.0978$ & $3-0.4564$ \\
\hline $\mathbf{K}_{2} \mathbf{O}$ & & & & & & & & & & & 1 & -0.1963 & $3-0.1984$ & 40.0819 & 0.6583 & $3-0.2417$ & 70.2086 & 0.0984 & -0.0662 & 20.1648 \\
\hline $\mathbf{H}_{2} \mathbf{O}+$ & & & & & & & & & & & & 1 & -0.4218 & $8-0.365$ & -0.2954 & 40.2541 & 0.1423 & 0.1041 & -0.005 & -0.0424 \\
\hline $\mathrm{Ni}$ & & & & & & & & & & & & & 1 & 0.429 & 0.0073 & $3-0.0018$ & $8-0.5629$ & $9-0.4311$ & $1-0.0747$ & 70.2016 \\
\hline Co & & & & & & & & & & & & & & 1 & 0.5297 & $7-0.347$ & $7-0.1564$ & $4-0.5655$ & $5-0.2778$ & 30.0288 \\
\hline $\mathrm{Pb}$ & & & & & & & & & & & & & & & 1 & -0.6955 & 50.0855 & -0.338 & -0.2282 & 20.3454 \\
\hline $\mathrm{Zn}$ & & & & & & & & & & & & & & & & 1 & -0.2832 & 20.3346 & -0.2687 & $7-0.125$ \\
\hline $\mathrm{Cr}$ & & & & & & & & & & & & & & & & & 1 & 0.2135 & 0.3407 & -0.4597 \\
\hline $\mathrm{Sr}$ & & & & & & & & & & & & & & & & & & 1 & -0.1375 & -0.378 \\
\hline $\mathrm{Li}$ & & & & & & & & & & & & & & & & & & & & 1 \\
\hline
\end{tabular}

higher concentration of silica is due to the presence of quartz and other siliceous minerals a characteristic feature of the original pellitic sedimentary rocks. Furthermore the high concentration of silica in the rocks of study area is possibly due to the presence of scapolite.

Silica shows a sympathetic relationship with $\mathrm{Al}_{2} \mathrm{O}_{3}, \mathrm{Fe}_{2} \mathrm{O}_{3}, \mathrm{P}_{2} \mathrm{O}_{5}$ and $\mathrm{K}_{2} \mathrm{O}(\mathrm{r}=0.732)$ (Table 6). The positive relationship of silica with these elements is possibly due to the presence of potash feldspar and other alumino-silicate minerals.

\subsection{Alumina $\left(\mathrm{Al}_{2} \mathrm{O}_{3}\right)$}

The alumina is negatively but insignificantly related with $\mathrm{MnO}$ (Figure 7(b)), $\mathrm{FeO}$ (Figure 7(c)), $\mathrm{TiO}_{2}, \mathrm{MgO}$, and $\mathrm{H}_{2} \mathrm{O}^{+}$and strongly antipathetic with $\mathrm{CaO}(\mathrm{r}=0.79$. As evident from the (Table 6), alumina shows positive relationship with $\mathrm{SiO}_{2}, \mathrm{Fe}_{2} \mathrm{O}_{3}\left(\mathrm{r}=0.73, \mathrm{P}_{2} \mathrm{O}_{5}, \mathrm{Na}_{2} \mathrm{O}\right.$ and $\left.\mathrm{K}_{2} \mathrm{O}\right)$. However, a strong positive relationship appears between $\mathrm{Al}_{2} \mathrm{O}_{3} \& \mathrm{Fe}_{2} \mathrm{O}_{3}(\mathrm{r}=0.73)$. By correlation coefficient it therefore appears that like other few oxides, e.g., FeO, $\mathrm{TiO}_{2}, \mathrm{MgO}, \mathrm{H}_{2} \mathrm{O}^{+}$, the alumina is also not significantly related with $\mathrm{MnO}$. Further the positive relationship of alumina with silica, $\mathrm{Fe}_{2} \mathrm{O}_{3}, \mathrm{Na}_{2} \mathrm{O}$ and $\mathrm{K}_{2} \mathrm{O}$ indicates the presence of sillimanite, kyanite, andalusite, orthoclase, microcline. The high $\mathrm{Al}_{2} \mathrm{O}_{3} / \mathrm{Fe}$ (total iron) ratio (Table 6) in both Khondalite and Charnockite is identical to that found in alumino-silicate minerals.

The abnormally high $\mathrm{Al}_{2} \mathrm{O}_{3}$ content is some samples of host rocks may be due to the presence of white specks of kaoline, found in cleavages and cracks of garnet [11]. These specks appear to be the cause of these abnormally high values. The abundance of alumina and silica can be assigned to the argillaceous nature of the parent rocks. 
Table 6. $\mathrm{Fe}_{2} \mathrm{O}_{3} / \mathrm{FeO}, \mathrm{SiO}_{2} / \mathrm{Al}_{2} \mathrm{O}_{3}, \mathrm{Na}_{2} \mathrm{O} / \mathrm{K}_{2} \mathrm{O}, \mathrm{CaO} / \mathrm{MgO}, \mathrm{MnO} / \mathrm{P}_{2} \mathrm{O}_{5}, \mathrm{MnO} / \mathrm{CaO}, \mathrm{Al}_{2} \mathrm{O}_{3} / \mathrm{TiO}_{2}, \mathrm{MnO} / \mathrm{Fe}$ (total iron) $\mathrm{Al}_{2} \mathrm{O}_{3} / \mathrm{Fe}$ (total iron) ratios of Khondalite and Charnockite Groups of Garividi, Garbham and Chipurupalle areas, Srikakulam-Visakhapatnam Belt (A.P.).

\begin{tabular}{|c|c|c|c|c|c|c|c|c|c|}
\hline Sample Nos. & $\mathrm{Fe}_{2} \mathrm{O}_{3} / \mathrm{FeO}$ & $\mathrm{SiO}_{2} / \mathrm{Al}_{2} \mathbf{O}_{3}$ & $\mathrm{Na}_{2} \mathbf{O} / \mathbf{K}_{2} \mathrm{O}$ & $\mathrm{CaO} / \mathrm{MgO}$ & $\mathbf{M n O} / \mathbf{P}_{2} \mathbf{O}_{5}$ & $\mathrm{MnO} / \mathrm{CaO}$ & $\mathrm{Al}_{2} \mathrm{O}_{5} / \mathrm{TiO}_{2}$ & $\begin{array}{c}\mathrm{MnO} / \mathrm{Fe} \\
\text { (Total Iron) }\end{array}$ & $\begin{array}{c}\mathrm{Al}_{2} \mathrm{O}_{3} / \mathrm{Fe} \\
\text { (Total Iron) }\end{array}$ \\
\hline 1 & 0.26 & 5.29 & 0.255 & 2.75 & 0.5 & 0.050 & 17.93 & 0.020 & 2.284 \\
\hline 2 & 0.318 & 5.22 & 0.322 & 2.22 & 1.2 & 0.049 & 33.62 & 0.031 & 3.539 \\
\hline 3 & 0.730 & 4.17 & 0.157 & 1.45 & 0.7 & 0.168 & 35.63 & 0.026 & 2.104 \\
\hline 4 & 0.099 & 7.60 & 33.5 & 2.51 & 0.94 & 0.047 & 10.7 & 0.065 & 0.445 \\
\hline 5 & 0.147 & 4.18 & 2.91 & 3.91 & 3.6 & 0.022 & 16.9 & 0.043 & 1.625 \\
\hline 6 & 0.366 & 6.25 & 7.5 & 2.98 & 0.42 & 0.014 & 18.86 & 0.109 & 6.67 \\
\hline 7 & 0.372 & 9.22 & 8.0 & 5.59 & 0.58 & 0.008 & 5.74 & 0.105 & 3.175 \\
\hline 8 & 0.305 & 2.99 & 3.87 & 1.52 & 0.88 & 0.045 & 18.35 & 0.042 & 1.853 \\
\hline 9 & 0.197 & 3.43 & 1.80 & 1.45 & 1.42 & 0.068 & 11.26 & 0.056 & 1.823 \\
\hline 10 & 0.331 & 3.68 & 2.21 & 1.47 & 1.57 & 0.076 & 22.25 & 0.058 & 1.795 \\
\hline 11 & 0.360 & 4.09 & 1.29 & 1.02 & 1.18 & 0.118 & 35.59 & 0.048 & 2.005 \\
\hline 12 & 0.284 & 5.17 & 0.094 & 1.22 & 0.23 & 0.051 & 18.50 & 0.021 & 2.445 \\
\hline 13 & 0.518 & 5.36 & 0.281 & 2.16 & 3.0 & 0.125 & 21.86 & 0.062 & 2.733 \\
\hline 14 & 0.732 & 4.14 & 1.03 & 1.45 & 0.74 & 0.208 & 34.16 & 0.032 & 2.062 \\
\hline 15 & 0.189 & 6.44 & 83.5 & 2.87 & 6.42 & 0.045 & 12.36 & 0.062 & 0.514 \\
\hline
\end{tabular}

The generally high concentration of alumina is possible due to the presence of alumina-silicate minerals, i.e., feldspar, micaceous minerals and sillimanite (in garnet-sillimanite gneisses). In feldspar $\mathrm{Si}^{4+}$ (radius $0.42 \AA$ ) is replaced by $\mathrm{Al}^{3+}$ (radius $0.50 \AA$ ) in Si-O tetrahedra [28].

\subsection{Manganese (MnO)}

The $\mathrm{MnO}$ shows strong antipathetic relationship with $\mathrm{SiO}_{2}(\mathrm{r}=-0.84)$ and $\mathrm{K}_{2} \mathrm{O}$ (Figure $7(\mathrm{~d})$ ), whereas it shows feebly negative relationship with $\mathrm{Al}_{2} \mathrm{O}_{3}$ and $\mathrm{P}_{2} \mathrm{O}_{5}$.

As evident from Table 4, the $\mathrm{MnO}$, in the Khondalite and Charnockites of the present area have strong positive relationship with $\mathrm{FeO}(\mathrm{r}=0.93)$ and $\mathrm{MgO}(\mathrm{r}=0.79)$ and slightly positive relationship with $\mathrm{Fe}_{2} \mathrm{O}_{3}, \mathrm{TiO}_{2}$, $\mathrm{Na}_{2} \mathrm{O}$ (Figure 7(e)), Cao (Figure 7(f)) and $\mathrm{H}_{2} \mathrm{O}^{+}, \mathrm{MnO} / \mathrm{CaO}$ ratio is constant. The positive relationship of $\mathrm{MnO}$ with $\mathrm{Fe}_{2} \mathrm{O}_{3}, \mathrm{FeO}$ and the constant $\mathrm{MnO} / \mathrm{Fe}$ (total iron) (Table 6) ratio indicate that iron and manganese were delivered in the same proportion. The constant $\mathrm{MnO} / \mathrm{Fe}$ ratio suggests coprecipitation of $\mathrm{Mn}$ and Fe under fairly oxidizing condition. The small quantity of manganese determined from the country rocks has most probably been derived from the manganese silicate minerals like manganese bearing garnets, pyroxenes, and other Mn bearing minerals presents in the host rocks ([14] [29]-[31]) possibly in association of ferruginous magnesium rich calc-granulite and garnet sillimanite gneiss and hypersthene gneisses.

\subsection{Iron Oxides}

The relationship of $\mathrm{Fe}_{2} \mathrm{O}_{3}$ with $\mathrm{TiO}_{2}, \mathrm{CaO}, \mathrm{MgO}, \mathrm{K}_{2} \mathrm{O}$ and $\mathrm{H}_{2} \mathrm{O}^{+}$is negative as $\mathrm{Fe}_{2} \mathrm{O}_{3}$ increase with the decrease of these elements or vice versa.

The antipathetic relationship of $\mathrm{Fe}_{2} \mathrm{O}_{3}$ with $\mathrm{MgO}$ in Khondalite and Charnockite rocks may be explained by the replacement of $\mathrm{Fe}^{3+}(0.67 \AA)$ by $\mathrm{Mg}^{2+}(0.66 \AA)$ [32]. The higher $\mathrm{FeO} / \mathrm{Fe}_{2} \mathrm{O}_{3}$ values is Khondalite from the Eastern Ghat granulite belt of India indicate lower oxidation conditions in Early Proterozoic [33]. In Eastern Ghat granulite belt of India the variation in $\mathrm{FeO} / \mathrm{Fe}_{2} \mathrm{O}_{3}$ ratio from one area to the other suggests that these sediments were deposited in different basins with different pH. Eh conditions of deposition [33]. The Khondalite and char- 
nockite rocks of the area under study, exhibit composition variation in iron (total iron), ranging from $1.64 \%$ to $14.41 \%$ and exhibit high $\mathrm{MgO}$ values. Random variation is also observed in $\mathrm{K}_{2} \mathrm{O}, \mathrm{Na}_{2} \mathrm{O}$ and iron in ternary diagram showing high and random distribution of $\mathrm{MgO}$ in Khondalites $(\Delta)$ and Charnockites ( $\bullet$ ) of Garividi, Garbham and Chipurupalle areas, Srikakulam-Visakhapatnam Belt (A.P.) $\mathrm{Fe}_{2} \mathrm{O}_{3}$ (Total Iron), (Table 7 and Table 8).

The significant relationship between various other oxides are also taken into consideration for example relationships of $\mathrm{Al}_{2} \mathrm{O}_{3}$ with $\mathrm{TiO}_{2}$ (Figure 8(a)), $\mathrm{CaO}$ with $\mathrm{MgO}$ (Figure 8(b)) and $\mathrm{Fe}_{2} \mathrm{O}_{3}$ (Figure 8(c)) and $\mathrm{FeO}$ (Figure 8(d)).

\subsection{Titania $\left(\mathrm{TiO}_{2}\right)$}

Titanium oxide shows positive correlation with $\mathrm{MnO}$, FeO, $\mathrm{P}_{2} \mathrm{O}_{5}, \mathrm{CaO}, \mathrm{MgO}$ and $\mathrm{Na}_{2} \mathrm{O}$ whereas $\mathrm{SiO}_{2}, \mathrm{Al}_{2} \mathrm{O}_{3}$ (Figure 8(a)), $\mathrm{Fe}_{2} \mathrm{O}_{3}, \mathrm{~K}_{2} \mathrm{O}$ and $\mathrm{H}_{2} \mathrm{O}^{+}$are negatively correlated with $\mathrm{TiO}_{2}$. The positive correlation of $\mathrm{TiO}_{2}$ with $\mathrm{CaO}(\mathrm{r}=0.34)$, $\mathrm{MgO}(\mathrm{r}=0.37)$ and $\mathrm{Na}_{2} \mathrm{O}(\mathrm{r}=0.26)$ clearly indicates that much of the $\mathrm{TiO}_{2}$ contains in Khondalite and Charnockite rocks were possibly derived from the titanium bearing minerals like sphene.

\subsection{Lime (CaO)}

The graph and computed correlation coefficient of calcium show positive relationship with $\mathrm{MnO}$ in relationship of $\mathrm{MnO}$ with $\mathrm{SiO}_{2}, \mathrm{Al}_{2} \mathrm{O}_{3}, \mathrm{FeO}, \mathrm{K}_{2} \mathrm{O}, \mathrm{Na}_{2} \mathrm{O}$ and $\mathrm{CaO}$ in Khondalite and Charnockite Groups of Garividi, Garbham and Chipurupalle areas, Srikakulam-Visakhapatnam Belt (A.P.), $\mathrm{FeO}, \mathrm{TiO}_{2}$ and $\mathrm{H}_{2} \mathrm{O}^{+}$and strongly positive relationship with $\mathrm{MgO}\left(\mathrm{r}=0.78\right.$ ), (Figure 8(b)). CaO show antipathetic relationship with $\mathrm{Fe}_{2} \mathrm{O}_{3}, \mathrm{P}_{2} \mathrm{O}_{5}$ and $\mathrm{Na}_{2} \mathrm{O}$ and strongly antipathetic relationship with $\mathrm{SiO}_{2}(\mathrm{r}=0.78), \mathrm{Al}_{2} \mathrm{O}_{3}(\mathrm{r}=-0.79)$ and $\mathrm{K}_{2} \mathrm{O}(\mathrm{r}=0.726)$. The ratio of $\mathrm{CaO}$ and $\mathrm{MnO}$ is constant. The Khondalite and Charnockite rocks of the study area having fairly high concentration of $\mathrm{CaO}$ (range from $1.25 \%$ to $25.61 \%$ ). Furthermore diopside, wollastonite, anorthite, scapolite, piedmontite and calcite also contributed varying proportion of $\mathrm{CaO}$ to the Khondalite and Charnockite rocks. The lime content seems to be of migmatitic origin [38]. The relationship between various other oxides are also taken into consideration for example relationships of $\mathrm{Fe}_{2} \mathrm{O}_{3}$ (Figure 9(a)), $\mathrm{SiO}_{2}$ with $\mathrm{FeO}$ (Figure 9(b) and Figure 9(c)) and in these host rocks of Garividi, Garbham and Chirpurupalle areas.

\subsection{Phosphorus $\left(\mathrm{P}_{2} \mathrm{O}_{5}\right)$}

The concentration of $\mathrm{P}_{2} \mathrm{O}_{5}$ is abnormally on the higher side in the manganese ores as well as in the host rocks of the study area. However, $\mathrm{P}_{2} \mathrm{O}_{5}$ shows insignificant negative relationship with $\mathrm{MnO}, \mathrm{FeO}, \mathrm{CaO}$ and $\mathrm{MgO}$.

The ratio of $\mathrm{MnO}$ and $\mathrm{P}_{2} \mathrm{O}_{5}$ is variably low and high. Whereas $\mathrm{P}_{2} \mathrm{O}_{5}$ shows positive relationship with $\mathrm{SiO}_{2}$, $\mathrm{Al}_{2} \mathrm{O}_{3}, \mathrm{Fe}_{2} \mathrm{O}_{3}, \mathrm{TiO}_{2}, \mathrm{Na}_{2} \mathrm{O}, \mathrm{K}_{2} \mathrm{O}$ and $\mathrm{H}_{2} \mathrm{O}^{+}$. The positive relationship of $\mathrm{P}_{2} \mathrm{O}_{5}$ with $\mathrm{SiO}_{2}, \mathrm{Al}_{2} \mathrm{O}_{3}$ and $\mathrm{K}_{2} \mathrm{O}$ appears

Table 7. Recalculted to 100 wt\% of bulk components $\left(\mathrm{Fe}_{2} \mathrm{O}_{3}+\mathrm{MgO}\right), \mathrm{Na}_{2} \mathrm{O}$ and $\mathrm{K}_{2} \mathrm{O}$ in Khondalite rocks of Garividi, Garbham and Chipurupalle areas, Srikakulam-Visakhapatnam Belt (A.P.).

\begin{tabular}{|c|c|c|c|}
\hline Sample No & $\left(\mathrm{Fe}_{2} \mathrm{O}_{3}+\mathrm{MgO}\right)$ & $\mathrm{Na}_{2} \mathrm{O}$ & $\mathbf{K}_{2} \mathbf{O}$ \\
\hline 1 & 46.9 & 10.8 & 42.2 \\
\hline 2 & 42.7 & 13.9 & 43.3 \\
\hline 3 & 77.9 & 3.0 & 19.0 \\
\hline 4 & 97.0 & 2.9 & 0.08 \\
\hline 5 & 92.9 & 5.2 & 1.8 \\
\hline 6 & 81.0 & 16.7 & 2.2 \\
\hline 7 & 78.4 & 19.1 & 2.3 \\
\hline 8 & 82.9 & 13.5 & 3.4 \\
\hline 9 & 77.8 & 14.2 & 7.9 \\
\hline 10 & 81.7 & 12.5 & 5.6 \\
\hline
\end{tabular}


Table 8. Recalculated to 100 wt\% of bulk components $\left(\mathrm{Fe}_{2} \mathrm{O}_{3}+\mathrm{MgO}\right), \mathrm{Na}_{2} \mathrm{O}$ and $\mathrm{K}_{2} \mathrm{O}$ in Charnockite rocks of Garividi, Garbham and Chipurupalle areas, Srikakulam-Visakhapatnam Belt (A.P.).

\begin{tabular}{cccc}
\hline Sample No & $\left.\mathbf{( F e}_{2} \mathbf{O}_{3}+\mathbf{M g O}\right)$ & $\mathbf{N a}_{2} \mathbf{O}$ & $\mathbf{K}_{2} \mathbf{O}$ \\
\hline 1 & 68.4 & 17.7 & 13.7 \\
2 & 53.2 & 4.0 & 42.6 \\
3 & 48.1 & 11.4 & 40.4 \\
4 & 67.4 & 16.5 & 16.0 \\
5 & 92.6 & 7.2 & 0.08 \\
\hline
\end{tabular}

$\mathrm{Fe}_{2} \mathrm{O}_{3}$ total iron.

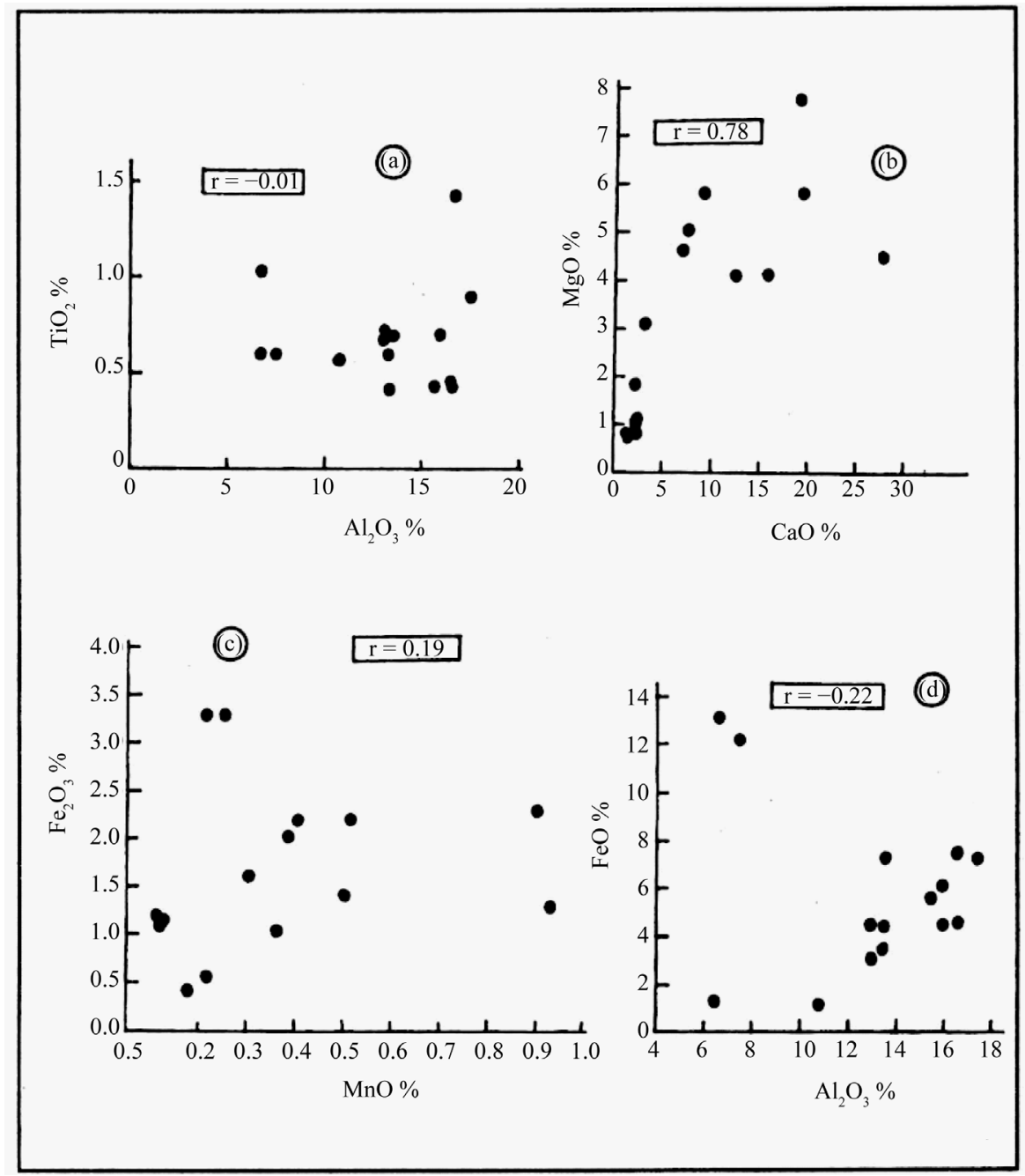

Figure 8. Relationship of $\mathrm{Al}_{2} \mathrm{O}_{3}$ with $\mathrm{TiO}_{2}$ and $\mathrm{FeO}$, and $\mathrm{CaO}$ with $\mathrm{MgO}$ and $\mathrm{MnO}$ with $\mathrm{Fe}_{2} \mathrm{O}_{3}$ in Khondalite and Charnockite Groups of Garividi, Garbham and Chipurupalle areas, Srikakulam-Visakhapatnam Belt (A.P.).

to be due to the presence of alumino-phosphate minerals probably leucophosphate formed by the reaction of phosphate rich solutions with clay minerals. The chemical reaction which indicates the formation of leucophosphate as given by [34] is as follows:

$$
\begin{aligned}
& \mathrm{Al}_{2} \mathrm{Si}_{2} \mathrm{O}_{5}(\mathrm{OH})_{4}+2 \mathrm{HPO}_{4}^{2-} \rightarrow 2 \mathrm{AlPO}_{4} \cdot 2 \mathrm{H}_{2} \mathrm{O}+2 \mathrm{SiO}_{2}+\mathrm{H}_{2} \mathrm{O} \\
& 2 \mathrm{AlPO}_{4} \cdot 2 \mathrm{H}_{2} \mathrm{O}+\mathrm{KOH} \rightarrow \mathrm{KAl}_{2}\left(\mathrm{PO}_{4}\right)_{2} \mathrm{OH} \cdot 2 \mathrm{H}_{2} \mathrm{O}+2 \mathrm{H}_{2} \mathrm{O}
\end{aligned}
$$


Further the positive relation of $\mathrm{P}_{2} \mathrm{O}_{5}$ with $\mathrm{Fe}_{2} \mathrm{O}_{3}$ clearly indicates the ferruginous nature of phosphate minerals. According in [1] [27] [31] [35], the source of phosphorus in the original manganiferous rocks is apatite and spessartite which are the common constituent of the rocks associated with gondite and Kodurite types.

[36] reported up to 4.10 percent $\mathrm{P}_{2} \mathrm{O}_{5}$ in spessartite. The presence of apatite in the host rocks indicates that they were subjected to metamorphism in a more hydrous environment as also suggested by [37].

The manganese silicate-carbonate, clay and silica. In few mines as in Avagudem the manganese carbonate was either deposited in the form of carbonate or formed through diagenesis of manganese oxide [39].

\subsection{Magnesia (Mg0)}

The present study reveals that $\mathrm{MgO}$ is positively correlated with $\mathrm{FeO}, \mathrm{CaO}, \mathrm{MnO}, \mathrm{TiO}_{2}, \mathrm{Na}_{2} \mathrm{O}$ and $\mathrm{H}_{2} \mathrm{O}^{+}$whereas it is negatively correlated with $\mathrm{Al}_{2} \mathrm{O}_{3}, \mathrm{Fe}_{2} \mathrm{O}_{3}, \mathrm{P}_{2} \mathrm{O}_{5}, \mathrm{SiO}_{2}$ and $\mathrm{K}_{2} \mathrm{O}$ (Figures 9(a)-(c)).

The Khondalites and Charnockites of the study area show higher concentration of MgO (ranges from $0.86 \%$ to 7.90\%). [33] also reported higher concentration of $\mathrm{MgO}$ in Khondalites from the Eastern Ghat granulite belt of India.

These Khondalite with high MgO content can be compared with Late-Archaean-Early Proterozoic metapelites. In the area under study the Khondalite and Charnockite rocks exhibit compositional variations (Table 9 and

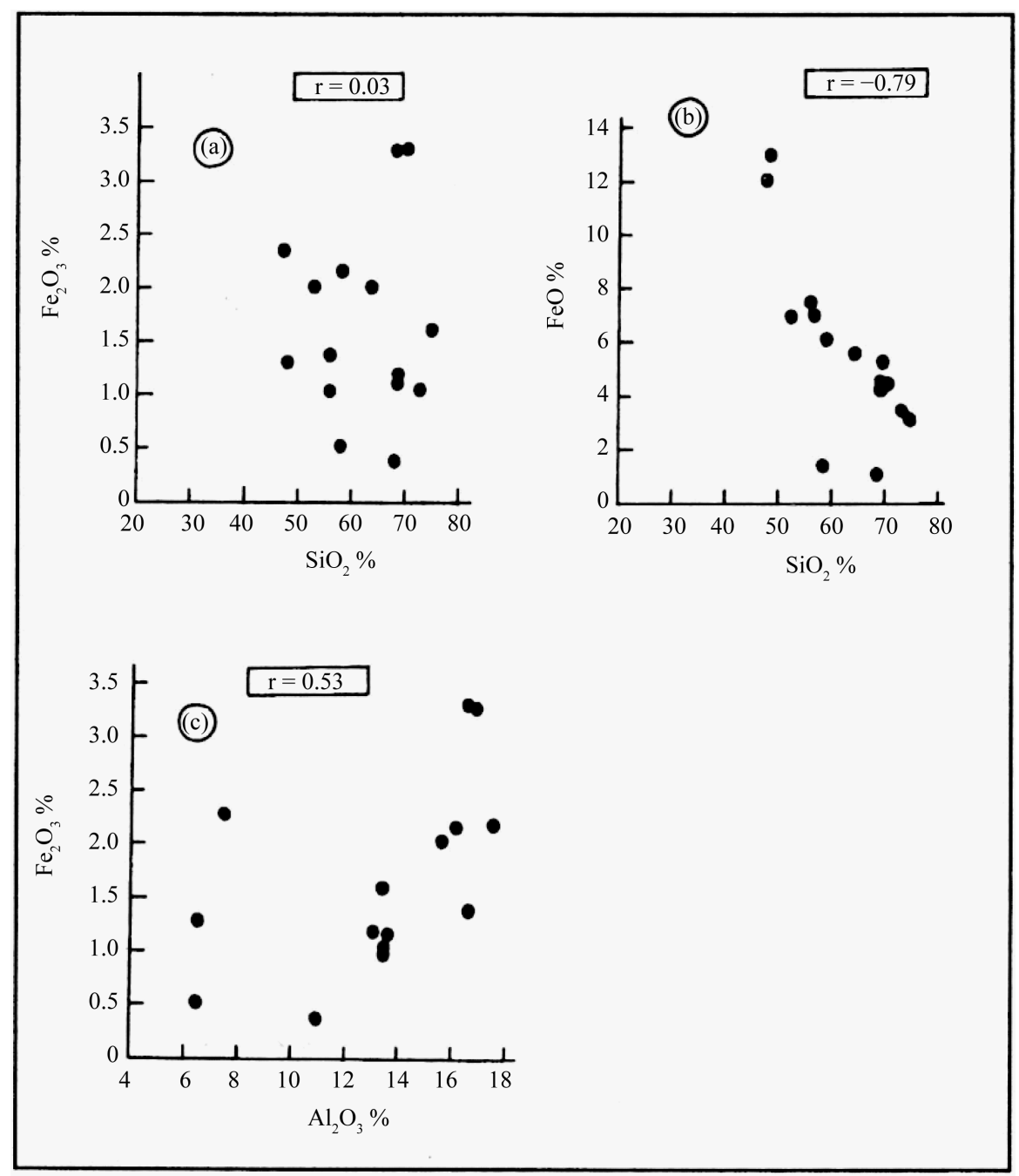

Figure 9. Relationship of $\mathrm{SiO}_{2}$ with $\mathrm{Fe}_{2} \mathrm{O}_{3}$ and $\mathrm{FeO}$ and $\mathrm{Al}_{2} \mathrm{O}_{3}$ with $\mathrm{Fe}_{2} \mathrm{O}_{3}$ in Khondalite and Charnockite Groups of Garividi, Garbham and Chipurupalle areas, Srikakulam-Visakhapatnam Belt (A.P.). 
Table 9. Recalculated to 100 wt\% of bulk components $\mathrm{MgO}, \mathrm{Na}_{2} \mathrm{O}$ and $\mathrm{K}_{2} \mathrm{O}$ in Khondalite rocks of Garividi, Garbham and Chipurupalle areas, Srikakulam-Visakhapatnam Belt (A.P.).

\begin{tabular}{|c|c|c|c|}
\hline Sample No & MgO & $\mathrm{Na}_{2} \mathrm{O}$ & $\mathbf{K}_{2} \mathbf{O}$ \\
\hline 1 & 10.3 & 18.2 & 71.3 \\
\hline 2 & 14.2 & 20.9 & 64.8 \\
\hline 3 & 25.5 & 10.1 & 64.2 \\
\hline 4 & 92.9 & 7.8 & .2 \\
\hline 5 & 81.4 & 13.7 & 4.7 \\
\hline 6 & 75.4 & 21.6 & 2.8 \\
\hline 7 & 71.7 & 25.0 & 3.1 \\
\hline 8 & 65.0 & 27.8 & 7.1 \\
\hline 9 & 55.8 & 28.4 & 15.7 \\
\hline 10 & 60.3 & 27.2 & 12.3 \\
\hline
\end{tabular}

Table 10) in $\mathrm{MgO}$ (ranges from $0.86 \%$ to $7.90 \%$ ), $\mathrm{K}_{2} \mathrm{O}$ (ranges from $0.02 \%$ to $5.94 \%$ ) and $\mathrm{Na}_{2} \mathrm{O}$ (ranges from $0.34 \%$ to $2.84 \%$ ). The ternary diagram (Figure 10 ) shows wide scatter distribution of $\mathrm{MgO}, \mathrm{K}_{2} \mathrm{O}$ and $\mathrm{Na}_{2} \mathrm{O}$.

The concentration of magnesium oxide is possibly due to the presence of garnet, spinel, hornblende, magnesium rich pyroxenes and biotite in the rocks of the study area. All these minerals pointing to the argillaceous nature of the original sediments which gave rise to these rocks.

\subsection{Soda $\left(\mathrm{Na}_{2} \mathrm{O}\right)$}

In the Khondalite and Charnockite rocks soda shows positive relationship with $\mathrm{Al}_{2} \mathrm{O}_{3}, \mathrm{MnO}$ in relationship of $\mathrm{MnO}$ with $\mathrm{SiO}_{2}, \mathrm{Al}_{2} \mathrm{O}_{3}, \mathrm{FeO}, \mathrm{K}_{2} \mathrm{O}, \mathrm{Na}_{2} \mathrm{O}$ and $\mathrm{CaO}$ in Khondalite and Charnockite Groups of Garividi, Garbham and Chipurupalle areas, Srikakulam-Visakhapatnam Belt (A.P.), $\mathrm{Fe}_{2} \mathrm{O}_{3}, \mathrm{FeO}, \mathrm{P}_{2} \mathrm{O}_{5}$ and $\mathrm{TiO}_{2}$.

These rocks in few samples show exceptionally high $\mathrm{Na}_{2} \mathrm{O} / \mathrm{K}_{2} \mathrm{O}$ ratio. The ternary diagram (Figure 11) shows wide scatter distribution of $\mathrm{K}_{2} \mathrm{O}$ and $\mathrm{Na}_{2} \mathrm{O}$.The presence of soda is due to the presence of feldspar and also due to the presence of scapolite in the Khondalites of study area [11]. The main supply of alkalies probably came from the igneous intrusion which cut across the Khondalite and Charnockite rocks. The high soda concentration in these rocks suggests the existence of predominantly tonalite/trondhjemite rocks in the source area. A study of granitic/gneissic episodes of the South Indian shield [40]-[42] indicates that the Early Archaean.

Post-greenstone granitic and gneissic episodes of the stable craton are mostly tonalitic/trondhjemitic in nature and K-rich granites appeared only in Late Proterozoic which explains better the high soda content in Proterozoic Khondalites of the Eastern Ghats. Predominance of soda rich tonalites and trondhjemites in Early Archean crust is also reported from other shield areas [43] [44]. Wide distribution in $\mathrm{Na}_{2} \mathrm{O}$ from area to area may indicate to different temperatures of Na-rich and mafic source material indifferent basins [33].

\subsection{Potash $\left(\mathrm{K}_{2} \mathrm{O}\right)$}

$\mathrm{K}_{2} \mathrm{O}$ shows insignificant negative relationship with $\mathrm{CaO}, \mathrm{MgO}, \mathrm{MnO}$ in relationship of $\mathrm{MnO}$ with $\mathrm{SiO}_{2}, \mathrm{Al}_{2} \mathrm{O}_{3}$, $\mathrm{FeO}, \mathrm{K}_{2} \mathrm{O}, \mathrm{Na}_{2} \mathrm{O}$ and $\mathrm{CaO}$ in Khondalite and Charnockite Groups of Garividi, Garbham and Chipurupalle areas, Srikakulam-Visakhapatnam Belt, $\mathrm{Fe}_{2} \mathrm{O}_{3}, \mathrm{FeO}, \mathrm{TiO}_{2}, \mathrm{Na}_{2} \mathrm{O}$ and $\mathrm{H}_{2} \mathrm{O}^{+}$. However, it shows strongly positive relationship with $\mathrm{SiO}_{2}$ and slightly positive relationship with $\mathrm{Al}_{2} \mathrm{O}_{3}$ and $\mathrm{P}_{2} \mathrm{O}_{5}$ (Table 4). The dominance of $\mathrm{K}_{2} \mathrm{O}$ over $\mathrm{Na}_{2} \mathrm{O}$ is characteristic of parametamorphic rocks [20] and these rocks have exceptionally high and variable $\mathrm{Na}_{2} \mathrm{O} / \mathrm{K}_{2} \mathrm{O}$ ratio. Potassium and sodium also show close coherence with aluminium, which is possibly due to the presence of soda and potash feldspar in these rocks.

\subsection{Water $\left(\mathrm{H}_{2} \mathrm{O}^{+}\right)$}

Water shows positive relationship with $\mathrm{MnO}, \mathrm{FeO}, \mathrm{P}_{2} \mathrm{O}_{5}, \mathrm{CaO}$ and $\mathrm{MgO}$ and negative relationship with $\mathrm{SiO}_{2}$, $\mathrm{Al}_{2} \mathrm{O}_{3}, \mathrm{Fe}_{2} \mathrm{O}_{3}, \mathrm{TiO}_{2}, \mathrm{Na}_{2} \mathrm{O}$ and $\mathrm{K}_{2} \mathrm{O}$. 
Table 10. Recalculated to $100 \mathrm{wt} \%$ of bulk components $\mathrm{MgO}, \mathrm{Na}_{2} \mathrm{O}$ and $\mathrm{K}_{2} \mathrm{O}$ in Charnockite rocks of Garividi, Garbham and Chipurupalle areas, Srikakulam-Visakhapatnam Belt (A.P.).

\begin{tabular}{ccccc}
\hline Sample No & MgO & $\mathbf{N a}_{2} \mathbf{O}$ & $\mathbf{K}_{2} \mathbf{O}$ \\
\hline 1 & 38.2 & 34.8 & 26.9 & 70.5 \\
2 & 22.7 & 6.6 & 66.4 \\
3 & 14.8 & 18.7 & 40.9 \\
5 & 16.8 & 42.2 & 0.2 \\
\hline
\end{tabular}

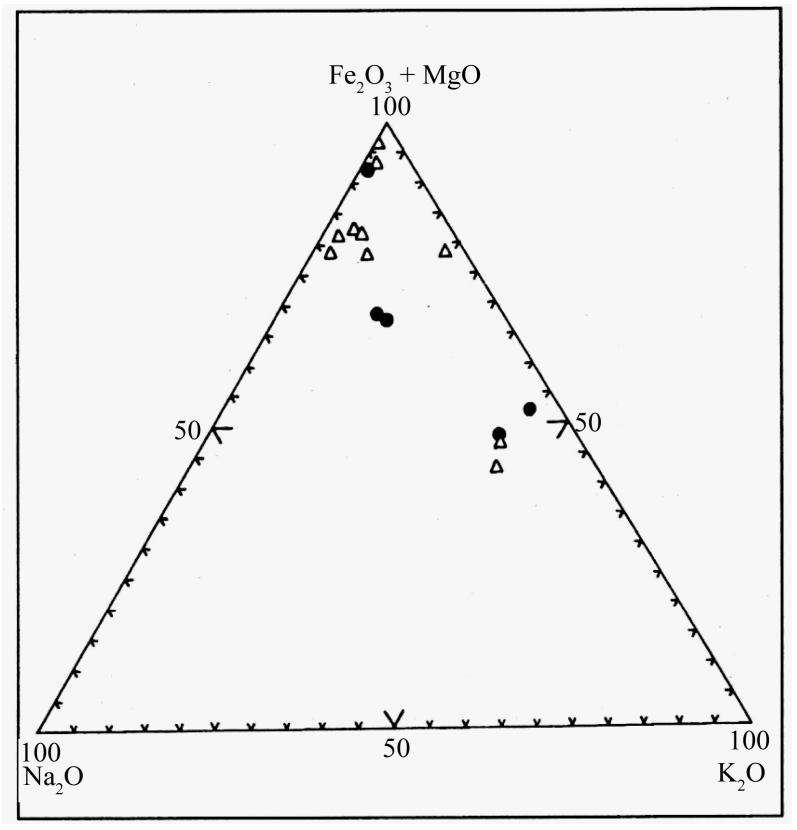

Figure 10. Ternary Diagram showing high and random distribution of $\mathrm{MgO}$ in Khondalites $(\Delta)$ and Charnockites $(\bullet)$ of Garividi, Garbham and Chipurupalle areas, Srikakulam-Visakhapatnam Belt (A.P.) $\mathrm{Fe}_{2} \mathrm{O}_{3}$ (Total Iron).

\section{Conclusions}

The analysis of 15 host rocks samples reveals that:

- Silica increases with the increases of $\mathrm{Al}$, phosphorous and potash and vice versa.

- Alumina increases with the increases of $\mathrm{SiO}_{2}, \mathrm{P}_{2} \mathrm{O}_{5}, \mathrm{Na}_{2} \mathrm{O}$ and $\mathrm{K}_{2} \mathrm{O}$ and vice versa.

- Mn increases with the increases of Fe and vice versa.

- $\mathrm{MnO}$ also shows strong sympathetic relationship with $\mathrm{MgO}$ and $\mathrm{Na}_{2} \mathrm{O}$.

- Phosphorous decreases with increase of $\mathrm{MnO}$ and vice versa.

- Ti increases with the increases of Mn and vice versa.

- Lime increases with the increases of Mn and vice versa.

- $\mathrm{Mg}$ increases with the increases of $\mathrm{MnO}$ and vice versa.

- Soda increases with the increases of both $\mathrm{Mn}$ and Fe and vice versa.

- Potash decreases with the increases of both Mn and Fe and vice versa.

The geochemical behavior of the host rocks indicate that the evolution of the ores took place in two different stage.

In first stage, sediments were rich in Mn, deposited in a basin during typical condition of oxidation. The chemical alteration and metamorphism of these sediments gave rise to the formation of primary metamorphic 


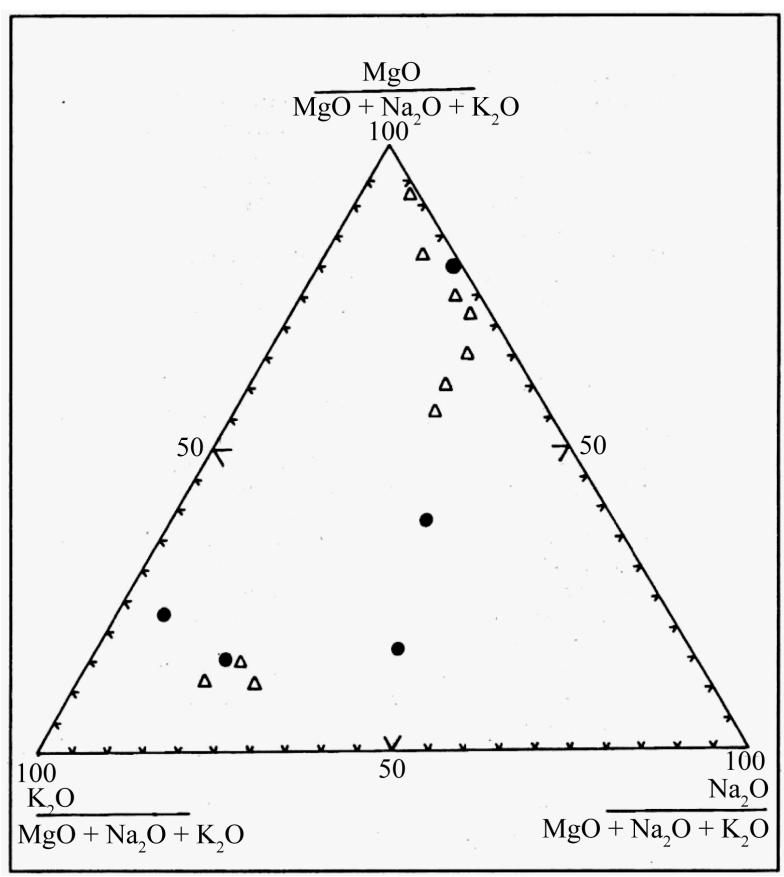

Figure 11. Ternary Diagram showing Wide Scatter of $\mathrm{Na}_{2} \mathrm{O}$ and $\mathrm{K}_{2} \mathrm{O}$ in Khondalites $(\Delta)$ and Charnockites $(\bullet)$ of Garividi, Garbham and Chipurupalle areas, Srikakulam-Visakhapatnam Belt (A.P.).

Mn minerals. In the later stages these metasediments suffered metasomatism due to intense igneous intrusions which caused hybridization at places.

In the second stage, the previously formed Mn ores and Mn-silicates of the country rocks like Mn-rich garnets and pyroxenes which played an important role in the formation of secondary Mn minerals viz. psilomelane-cryptomelane, hollandite, pyrolusite and wad etc. by the alteration. The meteoric water rich in $\mathrm{CO}_{2}$ played an important role in solution, transportation, precipitation, concentration and finally redeposition of the secondary Mn ores.

The concentration and redeposition have largely taken place from colloidal state or solution in oxidizing environment. It is assumed that $\mathrm{Mn}$ and $\mathrm{Fe}$ are in colloidal state. The anions and cations of minor and trace elements are adsorbed on the surface of negatively charged $\mathrm{Mn}(\mathrm{OH})_{4}$ and positively charged $\mathrm{Fe}(\mathrm{OH})_{3}$ particles. The high $\mathrm{K}_{2} \mathrm{O} / \mathrm{Na}_{2} \mathrm{O}, \mathrm{CaO} / \mathrm{MgO}$ and $\mathrm{Co} / \mathrm{Ni}$ ratios in these ores are due to high adsorption capacities of $\mathrm{K}_{2} \mathrm{O}$, $\mathrm{CaO}$ and $\mathrm{Co}$ then $\mathrm{Na}_{2} \mathrm{O}, \mathrm{MgO}$ and $\mathrm{Ni}$ :

Presumably the $\mathrm{Mn}$ and Fe solutions first form in feebly acidic medium with at $\mathrm{pH}$ value around 7. However with an increase in alkalinity $\mathrm{Mn}^{2+}$ and $\mathrm{Fe}^{2+}$ they are converted to colloidal $\mathrm{Mn}(\mathrm{OH})_{4}$ and $\mathrm{Fe}(\mathrm{OH})_{3}$. The solubility of $\mathrm{SiO}_{2}$ also increases with the increase $\mathrm{pH}$ (about 9), the $\mathrm{Al}_{2} \mathrm{O}_{3}$ dissolves into solution. The addition of $\mathrm{Al}(\mathrm{OH})_{3}$ into solution causes drastic changes in character of $\mathrm{Mn}(\mathrm{OH})_{4}$ colloids which are precipitated as oxide ores. Originally the Mn deposits have been derived from sources on the bordering Cratons, which are also the probable provinces for the sediments in this part of the basin.

\section{Acknowledgements}

The authors are grateful to Prof. M. Rahimullah, Chairman Department of Geology and Dean Faculty of Science, AMU Aligarh. To Director National Institute of Oceanography, Dona Paula, Goa for providing research facilities.

\section{References}

[1] Siddiquie, F.N. (2001) Source of Unusually High $\mathrm{P}_{2} \mathrm{O}_{5}$ in Manganese Ores of Srikakulam District (A.P.), India. Jour- 
nal of Applied Geochemistry, 3, 78-84.

[2] Siddiquie, F.N., Ali, S.A., Bhat, S.H. and Burhamuddin, Kh. (2015) Genetic Association of Trace Elements of with Special Emphasis on $\mathrm{Cu}, \mathrm{Ni}$, and $\mathrm{Cr}$ in the Manganese Ores of Vizianagaram District, (A.P.), India. Journal of Applied Geochemistry, 17, 66-77.

[3] Acharya, D.C. and Nayak, B.K. (2002) Mineral Chemistry of Manganese Ores Associated with Precambrian Eastern Ghats Complex of Andhra Pradesh, Orissa, India. In: Siddiquie, F.N., Ed., Metallogenesis of Manganese Ores of Srikakulam-Visakhapatnam Belt, Icon Publication Ltd., New Delhi, 213 p.

[4] Sarkar, S.N. (1968) Precambrian Stratigraphy and Geochronology of Peninsular India. Dhanbad Publishers, India, 33 p.

[5] Roy, S. (1966) Syngenetic Manganese Formations of India. Jadavpur University Press, Calcutta, 219 p.

[6] Mahnert, K.R. (1968) Migmatites and the Origin of Granitic Rocks. Els. Pub. Co., 393 p.

[7] Rao, G.V. (1969) The Geology and Manganese Ore Deposits of Parts of Vizakhapatnam (Visakhampatnam) Manganese Belt, Srikakulam District, A.P., India. Bulletin of Geological Survey of India, Series A, No. 35, 129 p.

[8] Fermor, L.L. (1909) Manganese Ore Deposits of India. Memoir of Geological Survey of India, 37, 272.

[9] Middlemiss, C.S. (1914) General Report of Geological Survey of India. Geological Survey of India, 36, 102-105.

[10] Rao, S.V.G.K. and Sarma, K.J. (1978) Report on Assessment of Manganese Ore in Srikakulam and Visakhapatnam Districts, A.P., India. Unpublished Report, Geological Survey of India.

[11] Prabhakhar Rao, G. (1950) The Geology of Manganese Bearing Rocks of Garividi and Garbham, Vizagapatnam District, A.P., India. Quarterly Journal of the Geological, Mining and Metallurgical Society of India, 22, 25-42.

[12] Venkataramaiah, K., Doshi, C.M. and Rao, S.V.G.K. (1978) A Report on the Assessment of the Manganese Ore Deposits in Srikakulam and Visakhapatnam District, A.P., India. Unpublished Report, Indian Bureau of Mines.

[13] Siddiquie, F.N. (1982) A Geochemical Appraisal of the Manganese Ores of Garividi, Garbham and Chirpurupalle mines, Srikakulam District, A.P., India. Unpublished M.Phil. Thesis, Geology Department, Aligarh Muslim University, Aligarh, $92 \mathrm{p}$.

[14] Siddiquie, F.N. (1986) Geology and Geochemistry of Manganese Ore Deposits of Srikakulam District (Andhra Pradesh), India. Unpublished Ph.D. Thesis, Geology Department, Aligarh Muslim University, Aligarh, 253 p.

[15] Siddiquie, F.N. (2000) On the Occurrence of Lepocinclis from Khondalites of Srikakulam District (A.P.). Bulletin of the Indian Geologist's Association, 33, 63-68.

[16] Siddiquie, F.N. (2003) Some Modification in the Stratigraphy of Manganese Bearing Formations, Srikakulam District (A.P.), India. Journal of Science and Technology, 11, 137-154.

[17] Siddiquie, F.N. (2004) Metallogenesis of Manganese Ores of Srikakulam-Visakhapatnam Belt. Icon Publication Pvt. Ltd., New Delhi, 194.

[18] Sharma, N.L., Ali, I. and Perraju, P. (1974) Geology of Parts of Srikakulam, Chipurupalli and Palakonda Taluks, Srikakulam District, A.P., India. Unpublished Report, Geol. Surv. India.

[19] The Indian Express (Express Newsline) (2002) Geologist Discovers New Green Alga. Science Talk, 7.

[20] Krishna Rao, J.S.R. (1954) The Geology of Chipurupalle Area, Vizagapatnam District, A.P., India, with Special Reference to the Origin of Manganese Ores. Quarterly Journal of the Geological, Mining and Metallurgical Society of India, 26, 36-44.

[21] Siddiquie, F.N. and Bhat, S.H. (2010) Geochemistry of Trace Elements in Manganese Ores and Their Host Rocks in Vizianagaram Manganese Ores Belt (A.P.), India. Journal of Applied Geochemistry, 10, 38-72.

[22] Janardhan, A.S., Newton, R.C. and Hansen, E.C. (1983) Transformation of Peninsular Gneiss to Charnockite in Southern Karnataka. Memoir 4, Geological Society of India. Proceedings of the Indo-U.S. Workshop, Hyderabad, 417-435.

[23] Krishna Rao, J.S.R. (1975) Some Problems on the Manganese Ore Deposits of A.P., India. Acta Mieralogica-Petrographica, 22, 133-141.

[24] Gupta, B.P. (1973) Petrology of Leptynites and Garnetiferous Apatite Gneiss around Garbham, Srikakulam District, A.P., India. Journal of the Geological Society of India, 14, 113-123.

[25] Krishnan, M.S. (1934) Khondalite from the Road between Banderwala and Nuwara, Eliya M.P. 1. Ceylon (Sri Lanka). Record of Geological Survey of India, 67, 395.

[26] Raghava Rao, K.V. (1955) In: Rao, G.V., 1959. The Geology and Manganese Ore Deposits of Parts of Vizakhapatnam (Visakhapatnam) Manganese Belt, Srikakulam District, A.P. India. Bulletin of Geological Survey of India, Series A, No. 35, 1-129.

[27] Mookherjee, A. (1961) Distribution of Minor Elements in the Gonditic Manganese Ore and Its Geochemical Signifi- 
cance. Economic Geology, 56, 723-729. http://dx.doi.org/10.2113/gsecongeo.56.4.723

[28] Rankama, K. and Sahama, Th.G. (1950) Geochemistry. University of Chicago Press, Chicago, 912 p.

[29] Siddiquie, F.N. and Raza, M. (1990) Major and Trace Elements Variability in Manganese Ores of Srikakulam District (A.P.). Indian Geologist’s Association, Chandigarh, Vol. 23, 99-109.

[30] Siddiquie, F.N. and Raza, M. (1990) Trace Elements in the Manganese Ores of Srikakulam Distt. (A.P.) India (Abstract). National Seminar on Precambrian Geology, Madras, 61.

[31] Siddiquie, F.N. and Raza, M. (2008) Geochemical Environment and Metallogenesis of Manganese Ores of Vizianagaram Manganese Belt Andhra Pradesh, India. Journal of the Indian Association of Sedimentologist, 27, 1-16.

[32] Drever, J.I. (1971) Magnesium Iron Replacement in Clay Minerals in Anoxic Marine Sediments. Science, 172, 13341336. http://dx.doi.org/10.1126/science.172.3990.1334

[33] Divakara Rao, V. (1983) Khondalites from the Eastern Ghat Granulite Belt Geochemistry and Origin. Geophysical Research Bulletin, 20, 233-242.

[34] Nriagu, J.O. (1972) Stability of Vivianite and Iron-Pair Formation of the System $\mathrm{Fe}_{3}\left(\mathrm{PO}_{4}\right)_{2}-\mathrm{H}_{3} \mathrm{PO}_{4}-\mathrm{H}_{2} \mathrm{O}$. Geochimica et Cosmochimica Acta, 36, 459-470. http://dx.doi.org/10.1016/0016-7037(72)90035-X

[35] Krishna Rao, J.S.R. and Venkataramaraju, D. (1966) A Study of Apatites from Srikakulam District, A.P., India. Quarterly Journal of the Geological, Mining and Metallurgical Society of India, 38, 177-181.

[36] Mason, B. and Berggren, T. (1941) A Phosphate-Bearing Spessartite Garnet from Wodgina, Western Australia. Geologiska Föreningen i Stockholm Förhandlingar, 63, 413-418. http://dx.doi.org/10.1080/11035894109445078

[37] Mitchell, L., Faust, G.T., Hendricks, S.B. and Reynolds, D.S. (1943) The Mineralogy and Genesis of Hydroxyl Apatite. American Mineralogist, 28, 356.

[38] Bhattacharyya, C. (1972) Granitisation in Relation to Evaluation of the Charnockite Series from the Eastern Ghat Hills, Srikakulam District, A.P., India. Neues Jahrbuch für Mineralogie Monatshefte, No. 5, 220-240.

[39] Bostrom, K. (1967) The Problem of Excess Manganese in Pelagic Sediments. In: Ableson, P.H., Ed., Researches in Geochemistry, Vol. 2, John Wiley and Sons, New York, 420-452.

[40] Naqvi, S.M., Divakara Rao, V. and Narain, H. (1978) The Primitive Crust: Evidence from the Indian Shield. Precambrian Research, 6, 323-345. http://dx.doi.org/10.1016/0301-9268(78)90021-9

[41] Ali, S. and Devakara Rao, V. (1980) Geochemistry and Origin of Acidic Rocks of Shimoga, Karnataka, India. Journal of Gelogical Society India, 21, 91-96.

[42] Divakara Rao, V. and Rama Rao, P. (1982) Granitic Activity and Crustal Growth in India Shield. Precambrian Research, 16, 257-271. http://dx.doi.org/10.1016/0301-9268(82)90063-8

[43] Sheraton, J.W. (1980) Geochemistry of Precambrian Metapelites from East Antarctica: Secular and Metamorphic Variations. Bureau of Mineral Resources Journal of Australia Geology and Geophysics, 5, 279-288.

[44] Glikson, A.Y. (1979) Early Precambrian Tonalite-Trondhjemite. 